\title{
Microbial Interkingdom Biofilms and the Quest for Novel Therapeutic Strategies
}

\author{
Katrien Van Dyck ${ }^{1,2}$, Rita M. Pinto ${ }^{1,2,3} \mathbb{D}$, Durgasruthi Pully ${ }^{1}$ and Patrick Van Dijck $1,2, *(\mathbb{D})$ \\ 1 Laboratory of Molecular Cell Biology, Institute of Botany and Microbiology, Department of Biology, \\ KU Leuven, 3001 Leuven, Belgium; katrien.vandyck@kuleuven.be (K.V.D.); \\ anaritaoliveiramacedo.pinto@kuleuven.be (R.M.P.); durgasruthi.pully@student.kuleuven.be (D.P.) \\ 2 VIB-KU Leuven Center for Microbiology, 3001 Leuven, Belgium \\ 3 LAQV, REQUIMTE, Departamento de Ciências Químicas, Faculdade de Farmácia, Universidade Do Porto, \\ 4050-313 Porto, Portugal \\ * Correspondence: patrick.vandijck@kuleuven.vib.be
}

check for updates

Citation: Van Dyck, K.; Pinto, R.M.; Pully, D.; Van Dijck, P. Microbial Interkingdom Biofilms and the Quest for Novel Therapeutic Strategies. Microorganisms 2021, 9, 412. https:// doi.org/10.3390/microorganisms9020412

Academic Editor: Adolfo

J. Martinez-Rodriguez

Received: 29 January 2021

Accepted: 15 February 2021

Published: 17 February 2021

Publisher's Note: MDPI stays neutral with regard to jurisdictional claims in published maps and institutional affiliations.

Copyright: (c) 2021 by the authors. Licensee MDPI, Basel, Switzerland. This article is an open access article distributed under the terms and conditions of the Creative Commons Attribution (CC BY) license (https:/ / creativecommons.org/licenses/by/ $4.0 /)$.

\begin{abstract}
Fungal and bacterial species interact with each other within polymicrobial biofilm communities in various niches of the human body. Interactions between these species can greatly affect human health and disease. Diseases caused by polymicrobial biofilms pose a major challenge in clinical settings because of their enhanced virulence and increased drug tolerance. Therefore, different approaches are being explored to treat fungal-bacterial biofilm infections. This review focuses on the main mechanisms involved in polymicrobial drug tolerance and the implications of the polymicrobial nature for the therapeutic treatment by highlighting clinically relevant fungal-bacterial interactions. Furthermore, innovative treatment strategies which specifically target polymicrobial biofilms are discussed.
\end{abstract}

Keywords: polymicrobial; biofilm; Candida; biofilm matrix; quorum sensing; antimicrobial peptides; essential oils; nanoparticles; probiotics

\section{Introduction}

Within the human body, microorganisms mostly exist in complex communities, including bacteria, fungi, and viruses [1]. In various niches of the host, interactions between fungi and bacteria frequently occur during infections [2]. The most diverse polymicrobial niches are the oral cavity and gastrointestinal tract; however, polymicrobial diseases may be located throughout the human body [1]. Both mucosal tissues and abiotic surfaces, such as catheters, dentures, and implants, are ideal surfaces for polymicrobial biofilm formation. Although it is widely accepted that the human body contains tremendous microbial diversity, most research was focused on bacteria while the fungal species, referred to as the mycobiome, were neglected [2]. Candida species, of which Candida albicans is the most prevalent, are commensal fungal species often involved in biofilm-related infections [3]. C. albicans is an opportunistic pathogen able to cause a variety of infections mainly in immunocompromised patients [4]. Other Candida species, including Candida glabrata, Candida tropicalis, Candida parapsilosis, Candida krusei, and Candida auris, are emerging as important causes of fungal infections as well [5]. These Candida species exhibit varying degrees of intrinsic resistance to the commonly used antifungal agents. The shift toward intrinsically resistant species, such as C. krusei and C. auris, in the epidemiology of Candida infections poses an additional medical concern [6,7]. Candida biofilm-associated infections are also a major challenge in clinical settings due to their intrinsic resistance to antifungals and the host immune response [8]. However, interactions of Candida species with bacteria in polymicrobial biofilms are an even bigger hurdle as they greatly impact the efficiency of the treatment strategy and the disease outcome [9]. C. albicans co-exists with commensal bacteria in several niches of the host and some of these fungal-bacterial interactions have a clear synergistic interaction, enhancing the pathogenicity of one or both species. 
Staphylococcus aureus is a Gram-positive commensal bacterium of healthy humans, but is also an opportunistic pathogen able to cause disease [10]. Among the wide variety of diseases ranging from superficial to life-threatening, methicillin-resistant $S$. aureus (MRSA) is an important cause of nosocomial infections [11,12]. C. albicans and S. aureus are often co-isolated from a variety of biofilm-associated diseases, including periodontitis, cystic fibrosis, and denture stomatitis, and they display a specific increased pathogenicity and enhanced drug tolerance [13-15]. A similar synergistic interaction is observed for C. albicans with Staphylococcus epidermidis, a Gram-positive commensal bacterium often involved in implant-associated infections [16]. Another bacterium often isolated together with C. albicans, especially from cystic fibrosis patients, is a Gram-negative bacterium Pseudomonas aeruginosa [17]. In contrast to the obviously synergistic interaction with $S$. aureus, the nature of the interaction with P. aeruginosa is not completely clear, and highly depends on the host and model system used to establish co-infection [18]. Streptococcal bacteria including Streptococcus oralis, Streptococcus mutans, Streptococcus gordonii, and Streptococcus sanguinis are the primary colonizers of the oral cavity. Interactions between oral bacteria and $C$. albicans tend to be mostly synergistic, stimulating the colonization and pathogenic potential of one or more microorganisms [19]. Several diseases of the oral cavity, including dental caries, endodontic infections, periodontal diseases, and denture-related infections, are associated with the formation of polymicrobial biofilms [20]. In addition, C. albicans provides a hypoxic microenvironment that supports the growth of anaerobic bacteria as well [21].

In clinical settings, polymicrobial diseases are increasingly recognized and are often accompanied with altered infection outcomes and therapeutic problems. The most obvious challenge in the treatment of interkingdom biofilms is the evolutionary distance between the disease-causing microorganisms, since the majority of antimicrobials target only one causative agent [22]. Standard treatment strategies for interkingdom polymicrobial infections, therefore, involve a combination of an antibacterial and antifungal drug. However, this approach has a poor efficacy, resulting in high chances of treatment failure [23,24]. The main reason is the specific increased drug tolerance and enhanced pathogenicity when the nature of the biofilm is polymicrobial, caused by a variety of factors including the biofilm matrix and quorum sensing [9]. Therefore, novel treatment strategies in which a sole agent can be used to prevent or eradicate polymicrobial biofilms are urgently needed. In this regard, alternative treatment strategies including antimicrobial peptides, plantderived components, quorum quenchers, probiotics, and the use of nanoparticles are being explored for the treatment of fungal-bacterial biofilm infections.

In this review, the main mechanisms that underlie this specific polymicrobial pathogenicity and drug tolerance and the implications of the polymicrobial nature for the therapeutic treatment and infection outcome are described, using clinically relevant fungal-bacterial interactions. Furthermore, drawbacks of existing therapeutic strategies are raised, and novel treatment strategies are highlighted.

\section{The Challenges of Targeting Interkingdom Biofilms}

\subsection{Enhanced Pathogenicity and Altered Infection Outcome}

The synergistic interaction between fungal and bacterial species often leads to an altered infection outcome related with higher morbidity and mortality rates. For example, C. albicans and S. aureus display a synergistic interaction leading to enhanced drug resistance and increased mortality in different mouse models $[23,25,26]$. The most common fungal biofilm-like infection of the oral cavity is oropharyngeal candidiasis (OPC), predominantly caused by C. albicans [27]. Since S. aureus is also commonly isolated from the oral cavity, a mouse model of oral C. albicans-S. aureus co-infection was developed [28-30]. Using this model, it was found that co-infected mice had both a higher oral colonization of $S$. aureus and were susceptible to a systemic $S$. aureus infection, whilst this was not the case for mono-infected mice $[29,30]$. Afterwards, research was focused on figuring out the mechanism of S. aureus dissemination when co-infected with C. albicans. Thereby, two important 
requirements for bacterial dissemination were identified: the physical interaction between both species via $C$. albicans agglutinin-like sequence (Als) 1 and 3 and the host immune response [31-33]. This increased mortality and morbidity was also observed in other animal models. In a peritoneal infection mouse model, an infection with both C. albicans and $S$. aureus was lethal whilst the corresponding mono-microbial infections were not $[26,34]$. A similar synergistic interaction is observed for $C$. albicans with $S$. epidermidis, the most commonly co-isolated bacteria from C. albicans bloodstream infections [16]. Using a polymicrobial biofilm model in Caenorhabditis elegans, increased mortality was observed for a C. albicans-S. epidermidis co-infection compared to mono-microbial infections [35].

Regarding $P$. aeruginosa, the nature of the interaction with C. albicans is not completely clear. Several studies suggested that $P$. aeruginosa inhibits growth of C. albicans in vitro, thereby defining the interaction as antagonistic [18]. The physical interaction between the two species, mediated by type IV pili, appeared to be required for killing of C. albicans hyphae $[36,37]$. Similar effects were observed in co-infection mouse models of lung infections where prior colonization of C. albicans resulted in increased P. aeruginosa clearance [38,39]. However, in a zebrafish infection model, increased C. albicans pathogenicity was observed in a co-infection with $P$. aeruginosa, and also in a mouse burn wound model, higher mortality rates were observed in co-infected mice $[40,41]$. In addition, clinical observations also indicate a potential synergistic interaction as Candida colonization in the respiratory tract of critically ill patients receiving mechanical ventilation increased the risk of $P$. aeruginosa ventilator-associated pneumonia [42].

The interaction of $C$. albicans with oral streptococcal bacteria tends to be mostly synergistic. Biofilm formation of oral streptococcal bacteria including S. gordonii, S. sanguinis, and S. oralis, was promoted by C. albicans on the surface of an oral mucosa analogue [43]. The physical interaction of $C$. albicans with $S$. gordonii was shown to be mediated by streptococcal surface proteins SspA and SspB and the Candida adhesin Als3 [44-46]. The oral opportunistic pathogen $S$. oralis was found to colonize better in the presence of $C$. albicans in an oral infection mouse model $[43,47]$. Clearly, numerous animal studies confirm the increased persistence, severity, and mortality of fungal-bacterial co-infections. Additionally, in clinical settings, diseases including infections of the oral cavity, cystic fibrosis, and diabetic foot wound infections are recognized as polymicrobial infections and the composition of the microbial population can predict the disease severity and outcome of the infection [1].

\subsection{The Biofilm Matrix: A Protective Shield}

Biofilms are embedded in a matrix consisting of extracellular polysaccharides (EPS), proteins, and extracellular DNA (eDNA). Interestingly, more matrix material is produced in polymicrobial biofilms [23]. In C. albicans-S. aureus or S. epidermidis polymicrobial biofilms, the enhanced tolerance towards antibiotics originates from the extracellular matrix of the biofilm which limits drug penetration [10]. One of the main polysaccharides of the C. albicans biofilm matrix, $\beta-1,3$-glucan, was shown to be the key constituent for S. aureusenhanced drug tolerance to vancomycin [48]. Likewise, extracellular polymers produced by S. epidermidis protected C. albicans against fluconazole by inhibiting penetration of the drug in a polymicrobial biofilm [49]. In addition, increased eDNA was observed in C. albicans$S$. epidermidis or $S$. aureus mixed biofilms, and degradation of this eDNA significantly increased the sensitivity of $C$. albicans to miconazole [50,51].

C. albicans extracellular matrix components also play an important role in enhancing drug resistance of $P$. aeruginosa [52]. It was recently shown that C. albicans $\alpha$-mannan and $\beta$-glucan polysaccharides increased the tolerance of $P$. aeruginosa to meropenem, directly impacting the treatment of co-infected cystic fibrosis patients [52]. In P. aeruginosa-C. albicans mixed biofilms, $C$. albicans enhances $P$. aeruginosa EPS production by increasing alginate-producing genes, $A \lg U$ and $m u c A$. Thus, the synergy between these two microorganisms leads to thicker biofilms with an easier bacterial dissemination [53]. However, this effect seems to be attenuated in the presence of $N$-acetyl-L-cysteine both in vitro and 
in an in vivo catheter-subcutaneous implantation model. This thiol-containing cysteine derivative is commonly known to disrupt disulfide bonds and cysteine utilization, exhibiting antimicrobial activity [54]. Hence, $N$-acetyl-L-cysteine may be a promising agent to prevent biofilm formation and to attenuate catheter-related sepsis due to its ability to inhibit matrix production on P. aeruginosa-C. albicans biofilms [53].

In C. albicans-S. mutans polymicrobial biofilms, bacterial EPS can bind and sequester fluconazole, thereby reducing the uptake and intracellular transport of the drug and enhancing $C$. albicans tolerance to this widely used azole drug [55]. In polymicrobial C. albicans-S. gordonii biofilms, the biofilm matrix components produced by C. albicans protected S. gordonii against antimicrobial treatment with clindamycin [56]. The polymicrobial biofilm architecture and composition of the biofilm matrix can be modified in several ways, thereby greatly influencing the drug susceptibility of the polymicrobial community [57]. Further research into the biofilm matrix components is crucial for the development of improved treatment strategies with a better penetration into the biofilm structure.

\subsection{Quorum Sensing: Communication is the Key}

Communication within microbial communities, referred to as quorum sensing (QS), is mediated by the secretion of small metabolites and plays an important role in biofilm formation. However, QS might play an even bigger role in polymicrobial biofilms [58]. In C. albicans-P. aeruginosa mixed biofilms, the QS molecule 3-oxo-C12 homoserine lactone was found to induce $C$. albicans resistance to fluconazole [59]. This is accomplished by facilitation of the ergosterol synthesis which is the target of fluconazole. In addition, upregulation of drug efflux and maintenance of cell wall integrity further contribute to this phenomenon. Other studies, however, indicated that this QS molecule is able to inhibit C. albicans filamentation without affecting fungal growth rates [60]. Interestingly, this QS molecule structurally resembles an important C. albicans QS molecule, farnesol, which also inhibits the morphological shift from yeast to hyphae $[59,61]$. In C. albicans-S. aureus mixed biofilms, farnesol is partly responsible for the enhanced tolerance of $S$. aureus to vancomycin, by inducing oxidative stress which in turn triggers the upregulation of drug efflux pumps [62]. In contrast, mixed biofilm formation of C. albicans with S. mutans was reduced in the presence of farnesol [63]. Farnesol treatment reduced the total biomass, metabolic activity, and cell viability. In addition, the treatment of C. albicans-S. aureus biofilms with a combination of farnesol and gentamicin enhanced the antimicrobial efficacy of gentamicin, demonstrating the synergy between these compounds [64]. A second important QS molecule in C. albicans is tyrosol, which stimulates C. albicans hyphal formation [65]. Similar to farnesol, an antibiofilm effect was observed for tyrosol against mixed biofilms consisting of C. albicans, C. glabrata, and S. mutans on acrylic resin and hydroxyapatite surfaces [66]. Farnesol and tyrosol were also investigated in the context of C. albicans-P. aeruginosa biofilms. Tyrosol was found to exert antibacterial activity against P. aeruginosa by inhibiting bacterial growth and inhibiting the production of virulence factors hemolysin and protease [67]. However, there was no effect on the antibiotic resistance of $P$. aeruginosa. Farnesol inhibited bacterial growth and hemolysin production to a lesser extent. In the case of $S$. gordonii, autoinducer 2 (AI-2), a group of molecules that promotes cross-communication between bacteria, was found to enhance C. albicans hyphal formation during polymicrobial biofilm growth [44].

Prostaglandin $\mathrm{E}_{2}$, produced by $C$. albicans, is an oxygenated metabolite of arachidonic acid which is upregulated during biofilm formation. Prostaglandin $\mathrm{E}_{2}$ functions as a regulator of host immune responses by stimulating the activation, maturation, and migration of immune-related host cells [68]. This molecule was found to stimulate growth and biofilm formation of $S$. aureus in C. albicans-S. aureus mixed biofilms [69]. The accessory gene regulator ( $a g r)$ QS system in $S$. aureus controls the expression of different virulence factors including $\alpha$-toxin, which mediates hemolytic activity and inflammasome activation, and reduces macrophages phagocytic killing. Significantly elevated levels of both Prostaglandin $\mathrm{E}_{2}$ and $\alpha$-toxin were observed during $C$. albicans-S. aureus co-infection in a mouse model of 
intraabdominal infection, while there was no difference in bacterial burden [70]. Further research should reveal the role of interspecies communication in fungal-bacterial biofilms and the possibility to target these QS systems in the treatment of co-infections. A major advantage of interfering with QS mechanisms is that it will control virulence and biofilm formation without causing a selective pressure.

\section{Novel Treatment Strategies}

Polymicrobial biofilms are usually more tolerant compared to their corresponding single species biofilms thereby limiting the possibility to use conventional drugs. However, voriconazole, a second-generation antifungal drug, was found to inhibit the interaction between C. albicans and Actinomyces viscosus, a Gram-positive bacterium associated with root caries, by inhibiting the ergosterol biosynthesis pathway [71]. In addition, the antifungal and antibacterial agents caspofungin and polymyxin B were able to reduce both the cell viability and total biomass of mixed biofilms consisting of P. aeruginosa with C. albicans, C. parapsilosis, C. tropicalis or C. glabrata [72]. The treatment of polymicrobial infections by using a combination of antibacterial and antifungal drugs is generally associated with a poor efficacy; however, combination therapy can also result in desirable outcomes. For example, in an intraabdominal catheter infection model in mice, it was found that anidulafungin acts synergistically with tigecycline against C. albicans-S. aureus mixed biofilms [73]. Similarly, an antimicrobial lock solution containing micafungin, doxycycline, and ethanol, used to sterilize infected catheters or medical devices, inhibited C. albicans-S. aureus mixed biofilms [74]. In addition, povidone iodine enhances the efficacy of fluconazole against mixed C. albicans-S. mutans biofilms by functioning as an EPS inhibitor through inhibition of $\alpha$-glucan synthesis [55]. However, alternative approaches are being explored to treat fungal-bacterial biofilm infections and are discussed below and summarized in Table 1.

Table 1. Summary of alternative treatment strategies for fungal-bacterial biofilms.

\begin{tabular}{|c|c|c|c|c|c|}
\hline Treatment & Strengths & Limitations & Examples & Biofilm Target & Ref. \\
\hline \multirow{4}{*}{$\begin{array}{l}\text { Antimicrobial } \\
\text { peptides }\end{array}$} & \multirow{4}{*}{$\begin{array}{c}\text { Broad-spectrum activity } \\
\text { Low toxicity } \\
\text { Low probability of resistance } \\
\text { Rapid } \\
\text { Efficient }\end{array}$} & \multirow{4}{*}{$\begin{array}{l}\text { Chemical instability } \\
\text { High production cost } \\
\text { Pharmacokinetic properties }\end{array}$} & gH625 analogues & $\begin{array}{l}\text { C. tropicalis-S. aureus-S. } \\
\text { marcescens } \\
\text { C. albicans-K. } \\
\text { pneumoniae }\end{array}$ & {$[75,76]$} \\
\hline & & & $\begin{array}{l}\text { cholic acid-peptide } \\
\text { conjugates }\end{array}$ & C. albicans-S. aureus & {$[77]$} \\
\hline & & & $\begin{array}{c}\text { guanylated } \\
\text { polymethacrylates }\end{array}$ & C. albicans-S. aureus & [78] \\
\hline & & & $\begin{array}{l}\varepsilon \text {-poly-L-lysine in } \\
\text { chitosan hydrogel }\end{array}$ & $\begin{array}{l}\text { P. aeruginosa-S. } \\
\text { aureus-C. albicans }\end{array}$ & [79] \\
\hline \multirow{2}{*}{$\begin{array}{l}\text { Quorum } \\
\text { quenchers }\end{array}$} & \multirow{2}{*}{$\begin{array}{l}\text { Selective pressure only under } \\
\text { QS conditions } \\
\text { Low probability of resistance }\end{array}$} & \multirow{2}{*}{$\begin{array}{c}\text { May disturb microbiota } \\
\text { homeostasis } \\
\text { May cause enhanced virulence }\end{array}$} & thiazolidinedione- 8 & C. albicans-S. mutans & {$[80,81]$} \\
\hline & & & QQ-5 and QQ-7 & C. albicans-S. epidermidis & {$[82]$} \\
\hline \multirow{6}{*}{$\begin{array}{l}\text { Plant-derived } \\
\text { components }\end{array}$} & \multirow{6}{*}{$\begin{array}{c}\text { Wide variety of } \\
\text { pharmaceutical and biological } \\
\text { activities } \\
\text { Low toxicity }\end{array}$} & \multirow{6}{*}{$\begin{array}{c}\text { High volatility } \\
\text { Low stability } \\
\text { Low bioavailability Small } \\
\text { scale production }\end{array}$} & citral and nepodine & C. albicans-S. aureus & {$[83,84]$} \\
\hline & & & $\begin{array}{l}\text { citrus EOs and } \\
\text { limonene }\end{array}$ & $\begin{array}{l}\text { P. aeruginosa- } A \text {. } \\
\text { fumigatus or } S \text {. } \\
\text { apiospermum }\end{array}$ & [85] \\
\hline & & & eugenol & C. albicans-S. mutans & {$[86]$} \\
\hline & & & curcumin & $\begin{array}{c}\text { C. albicans-S. aureus } \\
\text { C. albicans }-A \text {. baumannii }\end{array}$ & {$[87,88]$} \\
\hline & & & carvacrol & C. albicans-S. aureus & [89] \\
\hline & & & $\begin{array}{c}\text { Rhamnus prinoides } \\
\text { stem extract }\end{array}$ & C. albicans-S. mutans & {$[90]$} \\
\hline
\end{tabular}


Table 1. Cont

\begin{tabular}{|c|c|c|c|c|c|}
\hline Treatment & Strengths & Limitations & Examples & Biofilm Target & Ref. \\
\hline \multirow{3}{*}{$\begin{array}{l}\text { Photodynamic } \\
\text { therapy }\end{array}$} & \multirow{3}{*}{$\begin{array}{l}\text { Broad-spectrum activity } \\
\text { No toxicity } \\
\text { Low probability of resistance }\end{array}$} & \multirow{3}{*}{$\begin{array}{l}\text { Limited effect against biofilms } \\
\text { in vitro studies rarely translate } \\
\text { into animal models }\end{array}$} & $\begin{array}{l}\text { erythrosine-green } \\
\text { light }\end{array}$ & C. albicans-S. sanguinis & [91] \\
\hline & & & $\begin{array}{l}\text { acrylic resins doped } \\
\text { with Undaria } \\
\text { pinnatifida—blue light }\end{array}$ & $\begin{array}{c}\text { C. albicans-S. } \\
\text { sanguinis-S. mutans-L. } \\
\text { acidophilus }\end{array}$ & [92] \\
\hline & & & $\begin{array}{l}\text { Zn(II)chlorin e6 methyl } \\
\text { ester—red light }\end{array}$ & C. albicans-E. faecalis & [93] \\
\hline \multirow[t]{2}{*}{ Chitosan } & \multirow[t]{2}{*}{$\begin{array}{l}\text { No toxicity } \\
\text { BiodegradableLow cost } \\
\text { Good accessibility } \\
\text { Low immunogenicity }\end{array}$} & \multirow[t]{2}{*}{ Poor solubility in water } & \multirow[t]{2}{*}{ carboxymethyl chitosan } & $\begin{array}{c}\text { C. albicans-C. } \\
\text { tropicalis- } S . \\
\text { epidermidis-S. } \\
\text { salivarius- } R \text {. } \\
\text { dentocariosa-L. gasseri }\end{array}$ & {$[94,95]$} \\
\hline & & & & $\begin{array}{l}\text { C. tropicalis-S. } \\
\text { epidermidis }\end{array}$ & [96] \\
\hline Nanoparticles & $\begin{array}{c}\text { Enhanced bioavailability of } \\
\text { loaded drugs } \\
\text { Targeted delivery } \\
\text { Easier penetration inside } \\
\text { biofilm } \\
\text { Protection of drugs from } \\
\text { external environment }\end{array}$ & $\begin{array}{c}\text { Possible toxicity to } \\
\text { mammalian cells } \\
\text { Unknown processes of in vivo } \\
\text { metabolism } \\
\text { clearanceLong-term toxicity } \\
\text { Difficult scale-up } \\
\text { High-cost }\end{array}$ & $\begin{array}{c}\text { polymeric NPs } \\
\text { magnetic NPs } \\
\text { mesoporous silica NPs } \\
\text { silver NPs }\end{array}$ & cf. Table 2 & {$[97,98]$} \\
\hline \multirow{3}{*}{ Probiotics } & \multirow{3}{*}{$\begin{array}{l}\text { Restores and maintains the } \\
\text { balance of microbiota } \\
\text { Good accessibility } \\
\text { Easy to use }\end{array}$} & \multirow{3}{*}{$\begin{array}{l}\text { Limited survival of viable } \\
\text { probiotic cells } \\
\text { Lack of clinical studies and } \\
\text { mode-of-action studies }\end{array}$} & $\begin{array}{l}\text { S. boulardii-L. } \\
\text { acidophilus-L. } \\
\text { rhamnosus-B. breve } \\
\text { with amylase }\end{array}$ & $\begin{array}{l}\text { C. albicans or } C \text {. } \\
\text { tropicalis-E. coli-S. } \\
\text { marcenscens }\end{array}$ & [99] \\
\hline & & & $\begin{array}{l}\text { supernatant probiotic } \\
\text { Lactobacillus }\end{array}$ & $\begin{array}{c}\text { C. albicans-C. } \\
\text { tropicalis-S. salivarius }-R \text {. } \\
\text { dentocariosa-S. } \\
\text { epidermidis }\end{array}$ & [100] \\
\hline & & & L. salivarius & C. albicans-S. mutans & [101] \\
\hline
\end{tabular}

\subsection{Antimicrobial Peptides}

Antimicrobial peptides (AMPs) are short positively-charged molecules with an amphipathic character which are being explored as promising antimicrobial and antibiofilm compounds [102]. In nature, AMPs belong to the innate immunity of organisms to react against various pathogens and are, therefore, promising candidates in the development of new antibiotics. The main advantages are broad-spectrum activity, relatively low toxicity, rapid mechanism of action, and low probability of antimicrobial resistance. Several studies showed that AMPs can target bacteria and fungi by interacting with microbial membranes and disrupting the physical integrity $[103,104]$. However, the potential to use AMPs against polymicrobial infections has only been explored recently.

The membranotropic peptide gH625 (HGLASTLTRWAHYNALIRAF), derived from the herpes simplex virus type I, is a twenty-residue peptide which was shown to interact with and destroy membrane bilayers [105]. Later, this peptide was adapted by adding a sequence of lysine residues (gH625-GCGKKKK) which promotes both the interaction with negative charges of bacterial membranes and crossing of membrane bilayers and, therefore, interferes with biofilm formation [106]. The activity of the native and adapted peptide was assessed against monomicrobial and polymicrobial biofilms of C. tropicalis, S. aureus, and Serratia marcescens grown on silicone platelets. Although gH625 was not able to prevent C. tropicalis biofilm formation, the modified peptide displayed $90 \%$ inhibition. Similarly, for polymicrobial biofilms, the modified peptide showed a greater inhibition on biofilm formation compared to the native peptide. Both peptides appeared to be potent in the eradication of mature polymicrobial biofilms, likely due to the cell-penetrating capacity [75]. Recently, the antibiofilm activity of an analogue of the gH625 peptide, gH625-M (gH625GGGKKKK), was evaluated against polymicrobial C. albicans-Klebsiella pneumoniae biofilms 
in vitro and in vivo [76]. Subminimal inhibitory concentrations of gH625-M were able to inhibit the formation of both mono- and polymicrobial in vitro biofilms, as well as to eradicate them. Furthermore, the in vivo antimicrobial activity of gH625-M was evaluated for the first time using Galeria mellonella larvae infected with C. albicans and K. pneumoniae isolates. The mortality of larvae co-infected with C. albicans and K. pneumoniae was slightly higher compared to single species infections. gH625-M was nontoxic for the larvae and the administration of gH625-M after and, especially, before infection greatly improved larvae survival rates. In addition, gH625-M treatment before infection significantly reduced the expression of C. albicans biofilm-associated genes HWP1 and ALS3 [76].

Unfortunately, the high production cost of AMPs and the chemical instability and pharmacokinetic properties hampers the development of AMP-based treatments. Therefore, alternative studies are using the characteristics of AMPs as an inspiration to develop small molecules which target bacterial or fungal membranes. In this regard, cholic acid was recently investigated for its activity against bacterial, fungal, and polymicrobial biofilms [77]. Cholic acid is a naturally-occurring bile acid with an amphiphilic nature. By adapting this molecule to better resemble the amphiphilic and cationic characteristics of AMPs, nonpeptide compounds referred to as "ceragenins" were developed [107]. Subsequently, cholic acid-peptide conjugates (CAPs), in which dipeptide units are conjugated on a cholic acid backbone, were shown to effectively interact with lipopolysaccharides and the valine-glycine dipeptide-derived CAP 3 was shown to be the most effective against Gram-negative bacteria [108]. Recently, CAP 3 was also tested against C. albicans, S. aureus, and polymicrobial biofilms [77]. Treatment with CAP 3 degraded preformed polymicrobial biofilms, and the formation of polymicrobial biofilms on CAP 3-coated catheters was prevented. In addition, CAP 3 was shown to be effective in polymicrobial wound and catheter infection models in mice. In a wound infection model, mice treated three times daily with CAP 3 showed approximately 2 -log decreases in both S. aureus and C. albicans colonies. In a catheter infection model, CAP 3-coated catheters showed significant reductions in both bacterial and fungal loads [77].

Furthermore, AMP-mimicking synthetic polymers are under investigation for their anti-polymicrobial biofilm properties. These molecules have some considerable advantages as they are cheap and easy to produce and they can be chemically manipulated and integrated into drug delivery systems [109]. In this regard, guanylated polymethacrylates were synthesized, which are random copolymers of 2-guanidinoethyl methacrylate and methyl methacrylate, respectively, mimicking the cationic amino acid arginine and the lipophilic amino acid alanine. These molecules were recently shown to eradicate $C$. albicans-S. aureus polymicrobial biofilms in vitro [78]. Interestingly, when comparing the use of guanylated polymethacrylates with the use of different antimicrobial combinations, guanylated polymethacrylates were much more effective, with killing rates of $>94 \%$ for S. aureus and $>80 \%$ for C. albicans in the polymicrobial biofilm.

Finally, an ex vivo porcine wound biofilm model was developed to study the treatment of P. aeruginosa, S. aureus, and C. albicans polymicrobial biofilms [79]. As a treatment strategy, the natural peptide epsilon-poly-L-lysine was incorporated in a chitosan hydrogel and the antibiofilm efficiency was evaluated against mature polymicrobial biofilms ex vivo. The hydrogel was especially effective against $P$. aeruginosa when applied ex vivo to $24 \mathrm{~h}$ old polymicrobial wound biofilms; however, the activity was lower against $S$. aureus, and the hydrogel was ineffective against $C$. albicans. When the hydrogel was topically applied within $5 \mathrm{~h}$ after inoculation for 2 to 3 days, the biofilm thickness was reduced by at least $96 \%$ compared to untreated biofilms. Likewise, topical application of the hydrogel for $24 \mathrm{~h}$ to mature biofilms at 24 and $48 \mathrm{~h}$ after inoculation reduced biofilm thickness by $>70 \%$.

\subsection{Quorum Quenchers}

As described earlier, QS is a crucial process in polymicrobial biofilm formation and is, therefore, an interesting target for the development of novel treatment strategies. Interference in the process of QS, for example by inhibiting the synthesis or interaction of 
QS molecules, is referred to as quorum quenching. Quorum-quenching molecules have already been used as novel therapeutic agents combating bacterial or fungal biofilms; however, the possibility to use them against polymicrobial biofilms should be investigated further. Derivatives of thiazolidinediones, which are inhibitors of QS in the Gram-negative bacterium Vibrio harveyi, were developed as antibiofilm agents against C. albicans $[110,111]$. One of these derivatives, thiazolidinedione-8, profoundly affected C. albicans biofilm formation and was able to destroy preformed biofilms [111,112]. To further increase its therapeutic potential as a drug against oral candidiasis, thiazolidinedione- 8 was incorporated in a sustained-release membrane, thereby allowing a prolonged release of the drug in the oral cavity [113]. This inhibited C. albicans in vitro biofilm formation in a time-dependent manner and significantly eradicated mature biofilms. Additionally, it was shown that thiazolidinedione-8 decreases the biomass of $C$. albicans-S. mutans mixed biofilms in vitro, although no effect was observed against $S$. mutans, resulting in a favorable effect for S. mutans [80]. This was further investigated using a model system with constant flow conditions to mimic C. albicans-S. mutans mixed biofilm formation in the oral cavity [81]. Thiazolidinedione- 8 incorporated in a sustained-release membrane allowed better penetration of the compound in the mixed species biofilm, thereby affecting both pathogens by decreasing the biofilm metabolic activity and the production of EPS and altering the morphology of both pathogens.

Other quorum-quenching molecules were identified through functional screening of metagenomic large insert libraries. Two naturally-occurring quorum-quenching enzymes (QQ-5 and QQ-7) were found to potentially interfere with C. albicans and S. epidermidis biofilm formation [82]. QQ-5 and QQ-7 were able to prevent in vitro C. albicans biofilm formation by inhibiting the process of morphogenesis. Inhibition of S. epidermidis biofilm formation was likely due to the induction of a repressor for polysaccharide intracellular adhesin (PIA), which plays a key role in S. epidermidis biofilm formation. These findings highlight the potential of using such quorum-quenching molecules in targeting fungalbacterial biofilms. Non antibiotic pharmacological agents can be assessed for QS inhibition to identify new quorum-quenching molecules [114]. This drug development strategy is referred to as drug repurposing and offers some valuable advantages, as the toxicity and pharmacokinetic profile of these drugs are already established.

\subsection{Plant-Derived Components}

Plants protect themselves from microbial infections by the production of different types of antimicrobial molecules, including essential oils (EOs) and essential oil components. A large number of studies have been published where such compounds were tested for their antimicrobial or antibiofilm activity against either bacterial or fungal species [115-118]. More recently, several such molecules have also been tested in mixed fungal-bacterial settings. An example is citral, that shows strong activity against MRSA, where it targets biofilm specific pathways and also shows activity against different Candida species [119-121]. Recently, citral, as well as lemongrass, which is rich in citral and nepodin, were shown to have strong activity against dual-species C. albicans-S. aureus biofilms $[83,84]$. Citral resulted in lower biofilm biomass as well as in the number of viable cells of both species. The authors also showed that citral was interfering with the expression of Candida adhesins, as well as downregulating the expression of genes involved in the production of QS molecules, peptidoglycan, and fatty acids in S. aureus [84]. Nepodin, isolated from Rumex crispus, was shown to reduce the expression of hypha-specific genes and upregulated the expression of several transport genes [83]. Whereas citral was only tested in vitro, nepodin also affected C. albicans virulence in a nematode infection model system, but dual-species infections were not performed.

Citrus EOs obtained from pompia and grapefruit, and their major compound, limonene, were tested for their activity against mixed P. aeruginosa-Aspergillus fumigatus or Scedosporium apiospermum biofilms, which are relevant species in cystic fibrosis patients [85]. After a 24-h treatment, biofilms composed of P. aeruginosa and A. fumigatus were completely inhib- 
ited, and biofilms composed of P. aeruginosa and S. apiospermum were significantly reduced. Interestingly, these EOs showed the ability to interfere with the QS system of P. aerugonisa and to cause Candida membrane damage.

Eugenol, the major component of EOs from the Syzygium aromaticum plant (clove), was tested for its antibiofilm activity in the management of oral diseases [86]. A concentrationdependent antibiofilm activity was observed against polymicrobial C. albicans-S. mutans biofilms with a reduction in biofilm formation of $52 \%$ at a subminimal inhibitory concentration of eugenol. In addition, the cell viability was significantly reduced, and cell membranes and matrix structures were disrupted. Moreover, eugenol is nontoxic and safe for human use and should, therefore, be further evaluated in vivo. A combination therapy of conventional drugs with geranium, citronella, and clove EOs was also assessed against $C$. albicans-S. aureus biofilms [122]. Treatment of these preformed polymicrobial biofilms with fluconazole or mupirocin in combination with clove oil was the most effective and resulted in a 10-fold and 4-fold increase in antibiofilm activity of fluconazole and mupirocin, respectively.

Curcumin is a polyphenol isolated from the spice Curcuma longa (turmeric) with a wide range of pharmacological activities, including antibacterial and antifungal effects [123]. However, the antibiofilm activity against polymicrobial C. albicans-S. aureus biofilms was only explored recently. Curcumin significantly reduced the formation of both mono- and polymicrobial biofilms and was effective against preformed biofilms, although the effect was smaller [87]. Interestingly, the effect was enhanced when curcumin was combined with 2 -aminobenzimidazole. The antimicrobial effect of curcumin was also evaluated against mixed biofilms of $C$. albicans with Acinetobacter baumannii, a Gram-negative bacterium responsible for a variety of nosocomial infections [88]. Curcumin was able to reduce mixed biofilm formation by $>85 \%$ and reduced $A$. baumannii virulence in a C. elegans model without exhibiting toxicity; however, the in vivo activity against mixed biofilms was not assessed. Unfortunately, the therapeutic application of curcumin is hindered due to its instability and low bioavailability [124].

The phenolic essential oil component carvacrol has broad spectrum antimicrobial properties and was already proved to be effective against oral and vaginal candidiasis in vivo $[125,126]$. However, carvacrol has a poor solubility and high volatility, which limits the application potential. Therefore, drug delivery systems using electrospun nanofibers were explored to improve the stability and prolong the activity [89]. Carvacrol-containing polylactic acid electrospun nanofibrous membranes were evaluated against $C$. albicans-S. aureus biofilms. Carvacol was gradually released from the membrane which ensured an antimicrobial activity up to $144 \mathrm{~h}$. Both the formation of polymicrobial biofilms and metabolic activity, vitality, and biomass of preformed biofilms were reduced, indicating the potential of this compound for skin and wound infections [89]. Finally, a stem extract from the small Rhamnus prinoides tree (gesho) was able to inhibit S. mutans-C. albicans biofilm formation by $98 \%$, likely by reducing the EPS production [90].

\subsection{Photodynamic Therapy}

Photodynamic therapy involves the combination of visible light with nontoxic dyes, called photosensitizers, to kill microbial cells including bacteria, fungi, and viruses [127]. The photosensitizers are irradiated by light of the wavelength, which they are able to absorb to generate oxidized products and singlet oxygen capable of damaging essential cell components. Photodynamic therapy appears to be very promising within various subspecialties of dentistry by offering a minimally-invasive antimicrobial treatment modality. In addition, several photosensitizers are already approved for safe use in dentistry and there is no threat of antibiotic resistance against photodynamic therapy [128].

By using erythrosine as a photosensitizer and a green light-emitting diode, significant microbial reduction of both C. albicans and S. sanguinis in a mixed in vitro biofilm was observed [91]. However, mixed biofilms of C. albicans with S. sanguinis, S. mutans, or S. aureus were still more resistant to photodynamic inactivation compared to single species 
biofilms, likely due to the more complex biofilm matrix $[91,129,130]$. Erythrosine is already approved for use in dentistry and was used because of its nontoxic effect to the host. In addition, green LED light has some noteworthy advantages compared to other lasers, such as the cost, smaller size, and broader emission bands.

Furthermore, acrylic resins doped with Undaria pinnatifida, a brown seaweed microalga which contains the natural photoactive pigment chlorophyll-a, were used as photosensitizers in combination with blue light to target multispecies biofilms [92]. This study showed a dose-dependent reduction of viable microbial cells in biofilms of C. albicans, S. sanguinis, S. mutans, and Lactobacillus acidophilus and inhibition of biofilm formation of all microorganisms by $99 \%$.

Finally, photodynamic therapy was evaluated for the eradication of endodontic biofilms by using the photosensitizer Zn(II)chlorin e6 methyl ester, obtained from chlorophyll-a, in combination with red light [93]. In an in vitro model of endodontic C. albicans-Enterococcus faecalis biofilm, the photodynamic therapy was able to remove $60 \%$ of the biofilm mass and was, therefore, more efficient compared to other photosensitizers. In the endodontic field, a microbial infection in the root canal system caused by multispecies biofilms remains a common problem, which led to the emergence of photodynamic therapy in this field.

\subsection{Carboxymethyl Chitosan}

Chitosan is a natural polysaccharide polymer that has received increasing attention in the medical world because of its antimicrobial activity combined with a low cost, good accessibility, and low toxicity [131]. However, chitosan has a poor solubility in water, which has been resolved by carboxymethylation, yielding carboxymethyl chitosan (CMC). Chitosan is active on the cell surface of fungi and bacteria via electrostatic interactions, resulting in permeabilization of the cells. The antibiofilm effect of CMC was assessed against mixed fungal-bacterial biofilms developed on silicone plates, often used for the construction of medical devices and voice prostheses [94,95]. Mixed biofilms consisted of C. albicans, C. tropicalis, S. epidermidis, Streptococcus salivarius, Rothia dentocariosa, and Lactobacillus gasseri, all isolated from voice prostheses of laryngectomized patients. Treatment with CMC inhibited biofilm formation by approximately $73 \%$ and significantly decreased the biofilm metabolic activity. In addition, CMC inhibited Candida morphogenesis and adhesion of both fungi and bacteria. Furthermore, CMC could effectively inhibit both mono- and polymicrobial biofilms of $C$. tropicalis and S. epidermidis in microplates and on silicone surfaces [96]. Polymicrobial biofilms were inhibited by $56.2 \%$ and $54.7 \%$ on microtiter plates and on silicone surfaces, respectively. Although CMC itself displays antimicrobial activity, the effect of CMC can also be further enhanced with the use of various nanoparticles. In addition, further animal model studies are crucial for the evaluation of $\mathrm{CMC}$ in vivo.

\subsection{Nanoparticles}

A promising solution to overcome the limitations of conventional therapies is to employ the use of nanoparticles (NPs). Nanomaterials behavior is different from the bulk material, mainly due to their high surface area-to-volume ratio [132]. Consequently, nanostructures have mechanical, electrical, chemical, and magnetic properties that can be an advantage for drug delivery purposes. The small size of nanocarriers facilitates their penetration into the biofilm, ensuring the release of their antimicrobial contents locally. In addition, the small size allows efficient interaction with the microbial membrane and, eventually, with the nuclear content of the pathogen, thereby interfering with cellular processes [133]. The surface charge of the NPs also plays a role in the interaction with the biofilm, since positively-charged NPs bind to the negatively-charged EPS through electrostatic interactions, which allows them to reach deeper regions. Besides being a valuable tool as nanocarriers, NPs may also show intrinsic antimicrobial properties, such as silver and gold NPs [134]. These particles inhibit QS and generate reactive oxygen species 
(ROS), leading to cell damage [132,135]. Due to these unique characteristics, NPs have been explored to target polymicrobial biofilms (Table 2).

Table 2. Summary of nanoparticles developed as a therapeutic approach against interkingdom biofilms.

\begin{tabular}{|c|c|c|c|c|}
\hline Nanoparticles & $\begin{array}{c}\text { Formulation and } \\
\text { Associated Compounds }\end{array}$ & Applications & Mechanism of Action & Ref. \\
\hline \multirow{6}{*}{ Polymeric NPs } & $\begin{array}{l}\text { chitosan } \\
\text { sodiumtripolyphosphate } \\
\text { curcumin }\end{array}$ & $\begin{array}{l}\text { Medical devices-associated } \\
\text { infections } \\
\text { C. albicans-S. aureus }\end{array}$ & $\begin{array}{c}\text { Increase bioavailability } \\
\text { Enhanced antimicrobial } \\
\text { activity }\end{array}$ & [124] \\
\hline & $\begin{array}{l}\text { polylactic acid, dextran } \\
\text { sulfate, CTAB (cationic) } \\
\text { curcumin }\end{array}$ & $\begin{array}{l}\text { Oral biofilms } \\
\text { S. mutans-C. albicans-MRSA }\end{array}$ & $\begin{array}{c}\text { Increase bioavailability } \\
\text { Improve water solubility } \\
\text { Decrease cytotoxicity } \\
\text { Improve photodynamic effect }\end{array}$ & [136] \\
\hline & $\begin{array}{l}\text { chitosan } \\
\text { sodiumtriphosphate } \\
\text { Functionalization: } \\
\text { CDH, DNase I }\end{array}$ & $\begin{array}{l}\text { Medical devices-associated } \\
\text { infections } \\
\text { C. albicans-S. aureus }\end{array}$ & $\begin{array}{c}\text { Disrupt EPS } \\
\text { Enhanced antimicrobial } \\
\text { activity } \\
\text { Improve physical stability }\end{array}$ & [137] \\
\hline & $\begin{array}{c}\text { chitosan NPs } \\
\text { ozonated olive oil }\end{array}$ & $\begin{array}{l}\text { Endodontic infections } \\
\text { E. faecalis-S. mutans-C. } \\
\text { albicans }\end{array}$ & $\begin{array}{l}\text { Synergy between ozonated } \\
\text { olive oil and chitosan NPs }\end{array}$ & [138] \\
\hline & $\begin{array}{l}\text { chitosan } \\
\text { tripolyphosphate }\end{array}$ & $\begin{array}{l}\text { Early childhood caries } \\
\text { S. mutans-C. albicans }\end{array}$ & $\begin{array}{l}\text { Enhanced antimicrobial } \\
\text { activity }\end{array}$ & [139] \\
\hline & $\begin{array}{l}\text { alginate, copper } \\
\text { Solvents: EtOAc, DMC } \\
\text { A. platensis lipid extract }\end{array}$ & C. albicans-C. acnes & Increase bioavailability & [140] \\
\hline \multirow{3}{*}{ Magnetic NPs } & $\begin{array}{l}\text { iron chloride salts } \\
\text { ammonium hydroxide } \\
\text { Coating: aminosilane } \\
\text { chlorhexidine }\end{array}$ & $\begin{array}{l}\text { Oral biofilms } \\
\text { C. albicans-MRSA-P. } \\
\text { aeruginosa-E. faecalis }\end{array}$ & $\begin{array}{l}\text { Decrease effective dosage } \\
\text { Enhanced bioavailability } \\
\text { Enhanced biocompatibility } \\
\text { Enhanced antimicrobial } \\
\text { activity }\end{array}$ & [141] \\
\hline & $\begin{array}{l}\text { iron oxide NPs } \\
\text { Coating: chitosan } \\
\text { chlorhexidine }\end{array}$ & $\begin{array}{l}\text { Oral biofilms } \\
\text { C. albicans-S. mutans }\end{array}$ & $\begin{array}{l}\text { Decrease effective dosage } \\
\text { Enhanced bioavailability }\end{array}$ & [142] \\
\hline & $\begin{array}{l}\text { iron oxide NPs } \\
\text { Coating: chitosan } \\
\text { miconazole }\end{array}$ & $\begin{array}{l}\text { Caries, dentures, gingivitis } \\
\text { C. albicans-F. nucleatum-F. } \\
\text { nucleatum vincentii-V. } \\
\text { dispar-A. } \\
\text { naeslundii-Streptococci- } L \text {. } \\
\text { zeae-L. casei-R. dentocariosa }\end{array}$ & Increase bioavailability & {$[143,144]$} \\
\hline $\begin{array}{l}\text { Mesoporous silica } \\
\text { NPs }\end{array}$ & $\begin{array}{l}\text { CTAB, tetraethoxysilane } \\
\text { Functionalization: } \\
\text { phenazine-1-carboxamide }\end{array}$ & $\begin{array}{l}\text { Infections associated to } \\
\text { urethral catheters } \\
\text { C. albicans-S. aureus }\end{array}$ & $\begin{array}{l}\text { Increase bioavailability } \\
\text { Lower effective dosage } \\
\text { Controlled drug release }\end{array}$ & [145] \\
\hline \multirow{3}{*}{ Silver NPs } & silver nitrate & $\begin{array}{l}\text { Infections associated with } \\
\text { catheters } \\
\text { C. albicans-MRSA }\end{array}$ & $\begin{array}{l}\text { Enhanced antimicrobial } \\
\text { activity } \\
\text { Prevent surface colonization }\end{array}$ & {$[146,147]$} \\
\hline & $\begin{array}{l}\text { branched polyethylenimine } \\
\text { silver nitrate }\end{array}$ & $\begin{array}{l}\text { Biofilm-based nosocomial } \\
\text { infections } \\
\text { C. albicans-P. aeruginosa-S. } \\
\text { aureus }\end{array}$ & Prevent surface colonization & [148] \\
\hline & $\begin{array}{c}\text { polyamide, silver nitrate } \\
\text { Eucalyptus citriodora } \\
\text { leaves extract }\end{array}$ & $\begin{array}{c}\text { Ventilator-associated } \\
\text { pneumonia } \\
\text { C. albicans-P. aeruginosa-S. } \\
\text { aureus }\end{array}$ & $\begin{array}{l}\text { Prolonged antimicrobial } \\
\text { activity }\end{array}$ & [149] \\
\hline
\end{tabular}

NPs: nanoparticles; CTAB: cetyltrimethylammonium bromide; MRSA: methicillin-resistant S. aureus; CDH: cellobiose dehydrogenase; DNaseI: deoxyribonuclease I; EPS: extracellular polysaccharides; EtOAc: ethyl acetate; DMC: dimethyl carbonate. 
Several studies reported the use of NPs as drug delivery systems of natural compounds with antimicrobial properties. Taking advantage of the antimicrobial activity of curcumin, curcumin-loaded chitosan NPs were developed and tested against S. aureus and C. albicans mono- and polymicrobial biofilms [124]. The ability of these NPs to penetrate biofilms was evaluated, and NPs were observed both at the surface and deeper regions of the biofilm, which is likely a consequence of the NPs' positive charge, promoting its interaction with negatively-charged biofilm components and microbial cells. Thus, the low diffusion of free curcumin into the biofilm is overcome by encapsulation into NPs [124]. Curcumin-loaded NPs were more effective against preformed biofilms compared to free curcumin, with a biofilm reduction of $84.36 \%$. In a more complex approach, curcumin-loaded chitosan NPs were designed for antimicrobial photodynamic therapy, where the antimicrobial properties of the photosensitizer curcumin would be potentiated in the presence of light by ROS production $[150,151]$. The efficiency of anionic and cationic curcumin-loaded NPs was evaluated against mono-, dual-, and triple-species biofilms of MRSA, S. mutans, and C. albicans. For the anionic formulation, only S. mutans in mono-species biofilms was susceptible, possibly due to the repulsion between the NPs and the anionic components of the biofilm matrix [136]. Therefore, cetyltrimethylammonium bromide (CTAB) was further incorporated into the nanoformulation to produce cationic curcumin-loaded NPs. Both unloaded and curcumin-loaded cationic NPs showed a reduction of microbial viability in multi-species biofilms, even in the absence of light. This effect may be attributed to their positive charge, which promotes interactions with the microbial cell membrane [136]. Additionally, CTAB has been demonstrated to promote cell lysis of S. aureus, E. faecalis, and Escherichia coli [152]. Despite their potential, these cationic NPs are not safe systems for in vivo applications due to their cytotoxicity towards mammalian cells [136].

The previous studies showed the potential of nanocarriers to encapsulate antimicrobial agents. However, the biofilm matrix plays an important role in protecting microbial cells, thus, it is important to combine an approach that not only kills microbial cells but also disrupts matrix components [153]. In a combinatory strategy, cellobiose dehydrogenase (CDH) and deoxyribonuclease I (DNase I) were co-immobilized on chitosan NPs to target both microbial cells and the biofilm matrix [137]. CDH is widely used as an antimicrobial agent, while DNase I is able to degrade eDNA in the matrix of biofilms [154-156]. CDH-DNase NPs inhibited C. albicans-S. aureus mixed biofilm formation by $90.5 \%$ [137]. For preformed biofilms, the formulation showed a disruption higher than $80 \%$. Both $\mathrm{CDH}$ and DNase I were also immobilized separately into NPs (CDH NPs and DNase NPs, respectively) [137]. As expected, DNase NPs had no effect on biofilm since it is not able to kill microbial cells, which allows biofilms to be constantly formed even after dispersal. However, CDH-DNase NPs showed a higher antibiofilm activity than CDH NPs, indicating a synergistic effect of DNase I by improving NPs penetration into the biofilm. Therefore, the developed nanosystem may present a safe therapeutical strategy to eradicate polymicrobial biofilms [137]. In another study, the synergy between chitosan NPs and olive oil in the treatment of oral biofilms was assessed [138]. For this purpose, an ex vivo premolar teeth model was used to grown mature mixed biofilms of E. faecalis, S. mutans, and C. albicans. The combinatory treatment of olive oil and chitosan NPs led to a 6-log reduction of viable cells in only two days, while chitosan NPs or olive oil alone needed at least one week to provide acceptable viability reduction [138].

Despite their advantages as nanocarriers, chitosan NPs alone have been investigated as a therapeutical strategy against polymicrobial biofilms. The in vitro efficiency of chitosan NPs was assessed against $C$. albicans $-S$. mutans biofilm formation. A decreasing trend of remaining biofilm biomass and a significant cell viability decrease with the increase of concentration of chitosan NPs was observed [139]. Besides chitosan, other biocompatible polymers have been used in nanosystems for antibiofilm purposes. Recently, alginatebased nanocarriers loaded with lipid extracts from cyanobacteria Arthrospira platensis were developed. The activity of the extracted lipids was assessed in dual-species C. albicansCutibacterium acnes biofilms. The lipid-loaded alginate NPs were successful in inhibiting 
biofilm growth and disrupting preformed single-species $C$. albicans biofilms, which was not verified for the free lipid extracts. However, limited efficiency was observed when these NPs were tested in dual-species biofilms [140].

Recently, NPs with magnetic properties were explored as nanocarriers to eradicate polymicrobial biofilms. These NPs generate ROS and have, therefore, intrinsic antimicrobial activity [157]. Besides, magnetic NPs are advantageous for a targeted delivery to a specific site, since it is possible to guide them using an external magnetic field [157]. Chlorhexidine (CHX) was immobilized onto the magnetic NPs surface to enhance its antimicrobial activity [141]. Both free CHX and CHX-loaded magnetic NPs were tested in the presence of human saliva for its efficiency against multi-species oral biofilms. It was observed that immobilized $\mathrm{CHX}$ had an increased ability to restrict biofilm growth compared to free $\mathrm{CHX}$ at the same concentration. Additionally, the immobilized CHX did not exhibit cytotoxic effects against human osteoblast cells, while the free agent induced significant toxic effects [141]. To improve its biocompatibility and stability, CHX-loaded magnetic NPs were coated with chitosan [142]. The developed particles showed a significant reduction in biofilm biomass of dual-species C. albicans-S. mutans biofilms. The in vitro efficiency of the formulation was also assessed against preformed biofilms. The nanocarrier and the free CDX showed a metabolic activity reduction of $94.4 \%$ and $89.7 \%$ against dual-species biofilms, respectively. Thus, CDX-loaded nanocarriers may promote a higher antibiofilm effect of the drug, while lowering its toxicity toward human cells [142]. Magnetic NPs coated with chitosan were also used to load miconazole, a drug with both antibacterial and antifungal properties $[143,158]$. This formulation was further tested on three representative interkingdom oral biofilms (caries, denture, and gingivitis) [143]. In all three models, nanocarriers containing miconazole significantly reduced the number of viable cells. Interestingly, the formulation also promoted changes in the predominance of the different species composing the biofilm, with bacterial cells showing higher susceptibility to the treatment. In addition, fewer hyphae were observed in the presence of the designed NPs, which suggests an inhibition of $C$. albicans hyphal form during treatment. Consequently, the support provided by hyphae to bacteria is partially lost, explaining the lower numbers of bacterial cells [143].

The potential of NPs for the development of antimicrobial surface coatings to avoid biofilm formation has been also highly explored in the past years. Mesoporous silica NPs functionalized with phenazine-1-carboxamide (PCN) were produced to coat silicone urethral catheters. The authors assessed the antibiofilm activity of PCN extracted from $P$. aeruginosa and hypothesized that this metabolite induces ROS accumulation and reduction of ergosterol content. The NPs showed a controlled release of PCN over a 40-h period, which contributed to an inhibition higher than $88 \%$ of C. albicans-S. aureus biofilms. In fact, PCN-loaded NPs were able to inhibit mixed biofilms at a very low concentration compared to unloaded PCN [145]. In a distinct approach to inhibit formation of C. albicans-S. aureus biofilms in catheters, silicone elastomers were functionalized with silver NPs. The silver NPs effectively prevented mixed biofilm formation; however, the study lacks cytotoxicity assessment of the developed coating, which may hinder in vivo applications [147]. Silver NPs were also reported as a surface coating to avoid formation of $C$. albicans $-P$. aeruginosa biofilms [148]. Polyethylene and silicon substrates functionalized with silver NPs efficiently inhibited biofilm formation in P. aeruginosa monocultures, however this effect was not verified for mixed biofilms. It is believed that limited efficiency of silver NPs in coatings may be a consequence of a fast silver release from the NPs and moisture intake [148,149]. To overcome this drawback, a coating composed of silver NPs and polyamide was developed to decrease microbial adherence to endotracheal tubes [149].

\subsection{Probiotics}

Another strategy to target polymicrobial fungal-bacterial biofilms is the use of probiotics, which are defined as live microorganisms with beneficial effects on health when administered in adequate amounts. In patients with Crohn's disease, an inflammatory 
disease of the bowel, an increase in the abundance of C. albicans, C. tropicalis, E. coli, and S. marcescens was observed [159]. Therefore, probiotics which target these pathogenic microorganisms and support beneficial microorganisms are being explored in the setting of Crohn's disease [160]. A novel probiotic formulation was developed consisting of Saccharomyces boulardii, L. acidophilus, Lactobacillus rhamnosus, and Bifidobacterium breve combined with amylase for its antibiofilm activity. This probiotic formulation possessed antibiofilm activity against polymicrobial biofilms grown on silicone elastomer discs consisting of $C$. albicans or C. tropicalis in combination with E. coli and S. marcenscens by reducing the polymicrobial biofilm matrix and thickness and inhibiting Candida hyphal formation [99]. Polymicrobial biofilm growth of C. albicans, C. tropicalis, S. salivarius, R. dentocariosa, and S. epidermidis on silicone medical devices, such as voice prostheses, increases the risk of infection and limits the lifetime of the prosthesis. Therefore, the supernatant of probiotic Lactobacillus, containing exometabolites with antimicrobial activity, was tested as a treatment for these fungal-bacterial biofilms on silicone material [100]. This Lactobacilli supernatant was able to inhibit the adhesion and biofilm formation and reduce the polymicrobial biofilm metabolic activity. In addition, this probiotic treatment was able to inhibit Candida hyphal formation. The beneficial effects of probiotics were also explored in the context of early childhood caries, of which S. mutans is the main etiological agent [101]. Coexistence of $S$. mutans with $C$. albicans appears to be involved in dental caries progression and recurrence. A probiotic containing Lactobacillus salivarius was shown to decrease the biofilm mass and inhibit Candida hyphal formation in dual-species biofilms of $S$. mutans with C. albicans, thereby weakening its pathogenic potential.

\subsection{Other Treatment Strategies}

A series of compounds based on a 2-aminoimidazole scaffold were constructed and tested for their antibiofilm capacity against Salmonella Typhimurium and P. aeruginosa [161]. The nontoxic N1- and 2N-substituted 5-acryl-2-aminoimidazoles compounds were screened for antibiofilm activity against polymicrobial biofilms as well [162]. These compounds showed a strong activity against polymicrobial biofilm formation by Gram-positive bacteria and C. albicans; however, there was no activity against Gram-negative bacteria.

Dentures are an ideal surface for polymicrobial biofilm formation and can, therefore, lead to denture-related stomatitis. The possibility to reduce biofilm formation on polymethyl methacrylate denture material by incorporating antimicrobials into the material is being investigated [163]. The antimicrobial properties against mixed biofilms consisting of C. albicans, Lactobacillus casei, and S. mutans of a novel fluoride-releasing material were compared with a non-fluoridated copolymer. This study showed that the fluoride release significantly reduced the cell densities of all three species, highlighting the potential to include fluoride in dentures to control biofilm growth and subsequent diseases.

Bacteriophages are viruses which are able to infect bacteria and reproduce inside. The use of bacteriophages in phage therapy is a promising strategy against pathogenic bacterial infections and was shown to be effective against biofilm-related infections as well [164]. A few studies also investigated the activity of phages and the synergistic activity of phages with antibiotics against bacterial polymicrobial biofilms $[165,166]$. In addition, the possibilities of phage therapy are being explored in the context of nonbacterial infections [167]. In this context, it was shown that a bacteriophage of P. aeruginosa is not only able to inhibit $P$. aeruginosa biofilms, but also A. fumigatus and C. albicans biofilms [168]. Both biofilm formation and preformed biofilms of $C$. albicans were inhibited, likely by iron denial [169]. The drug repurposing strategy to use such phages for the treatment of mixed fungal-bacterial infections has not yet been explored but could have a lot of potential.

\section{Conclusions}

Polymicrobial diseases are increasingly being recognized in clinical settings and effective treatment strategies are lacking. Therefore, understanding the molecular mechanisms of the interactions between fungal and bacterial species in different niches of the host 
are of great importance. However, fungal-bacterial infections have been studied most extensively in the context of the oral microbial flora, and there is still a lack of research on these interactions in other anatomical areas or pathologies.

Although several promising techniques are highlighted here, the development of innovative therapeutic strategies to prevent interkingdom biofilms is still in its infancy. Several studies indicated the in vitro potential of antimicrobial peptides, plant-derived components, quorum quenchers, and probiotics, however, there remain hurdles to be overcome. The in vivo evaluation of the activity of these new therapeutic strategies in animal models and the assessment of possible toxicity are crucial but currently rather limited. Nanotechnology has also been highlighted as a promising tool to fight polymicrobial biofilms. Nanoparticles can be used as drug delivery systems to improve their antimicrobial effect, while decreasing their toxicity toward human cells. Besides, due to their small size, nanoparticles can reach deeper layers of the biofilm structure, leading to a higher concentration of antimicrobial agents in these regions. The intrinsic antimicrobial properties of nanoparticles have been also explored to overcome resistance phenomena and to avoid biofilm formation on medically relevant substrates. Although the reported studies showed in vitro efficacy against mixed biofilms, in vivo studies to evaluate the antibiofilm efficacy are lacking.

On a concluding note, the clinical need for the development of new strategies to target fungal-bacterial biofilm infections is high, and requires a good understanding of the interactions within these biofilms. In addition, some important properties of new drugs including broad-spectrum activity, no toxicity, and availability for oral administration should always be taken into account during the development [170]. Therefore, new components only rarely succeed from the preclinical to the clinical phase, and the quest for novel therapeutic strategies remains extremely challenging.

Author Contributions: Conceptualization: K.V.D. and P.V.D.; writing-original draft preparation: K.V.D., R.M.P., D.P., and P.V.D.; writing-review and editing: K.V.D., R.M.P., and P.V.D.; funding acquisition: P.V.D. All authors have read and agreed to the published version of the manuscript.

Funding: K.V.D. was supported by a personal research grant (1181818N) from the FWO (Fund for Scientific Research Flanders). R.M.P. is thankful to Fundação para a Ciência e Tecnologia (FCT) for her PhD grant (SFRH/BD/130319/2017). Work in the lab is supported by the FWO research community on biofilms (W000921N) and by the National Institute of Allergy and Infectious Diseases of the NIH under award number R01AI130170 (NIAID).

Data Availability Statement: The data presented in this study are available upon request from the corresponding author.

Conflicts of Interest: The authors declare no conflict of interest.

\section{References}

1. Peters, B.M.; Jabra-Rizk, M.A.; O’May, G.A.; Costerton, J.W.; Shirtliff, M.E. Polymicrobial Interactions: Impact on Pathogenesis and Human Disease. Clinical. Microbiol. Rev. 2012, 25, 193-213. [CrossRef] [PubMed]

2. Huseyin, C.E.; O'Toole, P.W.; Cotter, P.D.; Scanlan, P.D. Forgotten fungi-the gut mycobiome in human health and disease. FEMS Microbiol. Rev. 2017, 41, 479-511. [CrossRef]

3. Nobile, C.J.; Johnson, A.D. Candida albicans biofilms and human disease. Annu. Rev. Microbiol. 2015, 69, 71-92. [CrossRef]

4. Kim, J.; Sudbery, P. Candida albicans, a major human fungal pathogen. J. Microbiol. 2011, 49, 171-177. [CrossRef] [PubMed]

5. Deorukhkar, S.C.; Saini, S.; Mathew, S. Non-albicans Candida infection: An emerging threat. Interdiscip. Perspect. Infect. Dis. 2014, 2014, 615958. [CrossRef] [PubMed]

6. Arendrup, M.C.; Patterson, T.F. Multidrug-resistant Candida: Epidemiology, molecular mechanisms, and treatment. J. Infect. Dis. 2017, 216, S445-S451. [CrossRef] [PubMed]

7. Ksiezopolska, E.; Gabaldon, T. Evolutionary emergence of drug resistance in Candida opportunistic pathogens. Genes 2018,9 , 461. [CrossRef]

8. Gulati, M.; Nobile, C.J. Candida albicans biofilms: Development, regulation, and molecular mechanisms. Microbes Infect. 2016, 18, 310-321. [CrossRef]

9. Harriott, M.M.; Noverr, M.C. Importance of Candida-bacterial polymicrobial biofilms in disease. Trends Microbiol. 2011, 19, 557-563. [CrossRef] 
10. Carolus, H.; van Dyck, K.; van Dijck, P. Candida albicans and Staphylococcus species: A threatening twosome. Front. Microbiol. 2019, 10, 2162. [CrossRef]

11. Kong, E.F.; Johnson, J.K.; Jabra-Rizk, M.A. Community-associated methicillin-resistant Staphylococcus aureus: An enemy amidst us. PLoS Pathog. 2016, 12, e1005837. [CrossRef]

12. Gajdacs, M. The continuing threat of methicillin-resistant Staphylococcus aureus. Antibiotics 2019, 8, 52. [CrossRef]

13. Baena-Monroy, T.; Moreno-Maldonado, V.; Franco-Martinez, F.; Aldape-Barrios, B.; Quindos, G.; Sanchez-Vargas, L.O. Candida albicans, Staphylococcus aureus and Streptococcus mutans colonization in patients wearing dental prosthesis. Med. Oral. Patol. Oral. Cir. Bucal. 2005, 10, E27-E39.

14. Valenza, G.; Tappe, D.; Turnwald, D.; Frosch, M.; Konig, C.; Hebestreit, H.; Abele-Horn, M. Prevalence and antimicrobial susceptibility of microorganisms isolated from sputa of patients with cystic fibrosis. J. Cyst. Fibros. 2008, 7, 123-127. [CrossRef] [PubMed]

15. Cuesta, A.I.; Jewtuchowicz, V.; Brusca, M.I.; Nastri, M.L.; Rosa, A.C. Prevalence of Staphylococcus spp and Candida spp in the oral cavity and periodontal pockets of periodontal disease patients. Acta Odontol. Latinoam. 2010, 23, 20-26.

16. Klotz, S.A.; Chasin, B.S.; Powell, B.; Gaur, N.K.; Lipke, P.N. Polymicrobial bloodstream infections involving Candida species: Analysis of patients and review of the literature. Diagn. Microbiol. Infect Dis. 2007, 59, 401-406. [CrossRef] [PubMed]

17. Fourie, R.; Ells, R.; Swart, C.W.; Sebolai, O.M.; Albertyn, J.; Pohl, C.H. Candida albicans and Pseudomonas aeruginosa interaction, with focus on the role of eicosanoids. Front. Physiol. 2016, 7, 64. [CrossRef] [PubMed]

18. Fourie, R.; Pohl, C.H. Beyond antagonism: The interaction between Candida species and Pseudomonas aeruginosa. J. Fungi 2019, 5, 34. [CrossRef] [PubMed]

19. Kruger, W.; Vielreicher, S.; Kapitan, M.; Jacobsen, I.D.; Niemiec, M.J. Fungal-bacterial interactions in health and disease. Pathogens 2019, 8, 70. [CrossRef]

20. O'Donnell, L.E.; Millhouse, E.; Sherry, L.; Kean, R.; Malcolm, J.; Nile, C.J.; Ramage, G. Polymicrobial Candida biofilms: Friends and foe in the oral cavity. FEMS Yeast Res. 2015, 15, fov077. [CrossRef]

21. Fox, E.P.; Cowley, E.S.; Nobile, C.J.; Hartooni, N.; Newman, D.K.; Johnson, A.D. Anaerobic bacteria grow within Candida albicans biofilms and induce biofilm formation in suspension cultures. Curr Biol. 2014, 24, 2411-2416. [CrossRef] [PubMed]

22. Brogden, K.A.; Guthmiller, J.M.; Taylor, C.E. Human polymicrobial infections. Lancet 2005, 365, 53-55. [CrossRef]

23. Harriott, M.M.; Noverr, M.C. Candida albicans and Staphylococcus aureus form polymicrobial biofilms: Effects on antimicrobial resistance. Antimicrob. Agents Chemother. 2009, 53, 3914-3922. [CrossRef]

24. Kim, S.H.; Yoon, Y.K.; Kim, M.J.; Sohn, J.W. Risk factors for and clinical implications of mixed Candida/bacterial bloodstream infections. Clin. Microbiol. Infect. 2013, 19, 62-68. [CrossRef]

25. Harriott, M.M.; Noverr, M.C. Ability of Candida albicans mutants to induce Staphylococcus aureus vancomycin resistance during polymicrobial biofilm formation. Antimicrob. Agents Chemother. 2010, 54, 3746-3755. [CrossRef] [PubMed]

26. Carlson, E. Synergistic effect of Candida albicans and Staphylococcus aureus on mouse mortality. Infect. Immun. 1982, 38, 921-924. [CrossRef]

27. Swidergall, M.; Filler, S.G. Oropharyngeal Candidiasis: Fungal invasion and epithelial cell responses. PLoS Pathog. 2017, 13, e1006056. [CrossRef]

28. McCormack, M.G.; Smith, A.J.; Akram, A.N.; Jackson, M.; Robertson, D.; Edwards, G. Staphylococcus aureus and the oral cavity: An overlooked source of carriage and infection? Am. J. Infect. Control. 2015, 43, 35-37. [CrossRef]

29. Kong, E.F.; Kucharikova, S.; van Dijck, P.; Peters, B.M.; Shirtliff, M.E.; Jabra-Rizk, M.A. Clinical implications of oral candidiasis: Host tissue damage and disseminated bacterial disease. Infect. Immun. 2015, 83, 604-613. [CrossRef] [PubMed]

30. Schlecht, L.M.; Peters, B.M.; Krom, B.P.; Freiberg, J.A.; Hansch, G.M.; Filler, S.G.; Jabra-Rizk, M.A.; Shirtliff, M.E. Systemic Staphylococcus aureus infection mediated by Candida albicans hyphal invasion of mucosal tissue. Microbiology 2015, 161, 168-181. [CrossRef] [PubMed]

31. Allison, D.L.; Scheres, N.; Willems, H.M.E.; Bode, C.S.; Krom, B.P.; Shirtliff, M.E. The host immune system facilitates disseminated Staphylococcus aureus disease due to phagocytic attraction to Candida albicans during coinfection: A case of bait and switch. Infect. Immun. 2019, 87, e00137-19. [CrossRef] [PubMed]

32. Peters, B.M.; Ovchinnikova, E.S.; Krom, B.P.; Schlecht, L.M.; Zhou, H.; Hoyer, L.L.; Busscher, H.E.; van der Mei, H.C.; Jabra-Rizk, M.A.; Shirtliff, M.E. Staphylococcus aureus adherence to Candida albicans hyphae is mediated by the hyphal adhesin Als3p. Microbiol. SGM 2012, 158, 2975-2986. [CrossRef]

33. Van Dyck, K.; Viela, F.; Mathelié-Guinlet, M.; Demuyser, L.; Hauben, E.; Jabra-Rizk, M.A.; Vande Velde, G.; Dufrêne, Y.F.; Krom, B.P.; Van Dijck, P. Adhesion of Staphylococcus aureus to Candida albicans during co-infection promotes bacterial dissemination through the host immune response. Front. Cell. Infect. Microbiol. 2021, 10, 916. [CrossRef]

34. Carlson, E. Effect of strain of Staphylococcus aureus on synergism with Candida albicans resulting in mouse mortality and morbidity. Infect. Immun. 1983, 42, 285-292. [CrossRef]

35. Holt, J.E.; Houston, A.; Adams, C.; Edwards, S.; Kjellerup, B.V. Role of extracellular polymeric substances in polymicrobial biofilm infections of Staphylococcus epidermidis and Candida albicans modelled in the nematode Caenorhabditis elegans. Pathog. Dis. 2017, 75, ftx052. [CrossRef]

36. Hogan, D.A.; Kolter, R. Pseudomonas-Candida interactions: An ecological role for virulence factors. Science 2002, $296,2229-2232$. [CrossRef] [PubMed] 
37. Grainha, T.; Jorge, P.; Alves, D.; Lopes, S.P.; Pereira, M.O. Unraveling Pseudomonas aeruginosa and Candida albicans communication in coinfection scenarios: Insights through network analysis. Front. Cell Infect. Microbiol. 2020, 10, 550505. [CrossRef] [PubMed]

38. Ader, F.; Jawhara, S.; Nseir, S.; Kipnis, E.; Faure, K.; Vuotto, F.; Chemani, C.; Sendid, B.; Poulain, D.; Guery, B. Short term Candida albicans colonization reduces Pseudomonas aeruginosa-related lung injury and bacterial burden in a murine model. Crit Care 2011, 15, R150. [CrossRef]

39. Faure, E.; Bortolotti, P.; Kipnis, E.; Faure, K.; Guery, B. Studying microbial communities in vivo: A model of host-mediated interaction between Candida Albicans and Pseudomonas Aeruginosa in the airways. J. Vis. Exp. 2016, 107, e53218.

40. Bergeron, A.C.; Seman, B.G.; Hammond, J.H.; Archambault, L.S.; Hogan, D.A.; Wheeler, R.T. Candida albicans and Pseudomonas aeruginosa interact to enhance virulence of mucosal infection in transparent zebrafish. Infect. Immun. 2017, 85, e00475-17. [CrossRef] [PubMed]

41. Neely, A.N.; Law, E.J.; Holder, I.A. Increased susceptibility to lethal Candida infections in burned mice preinfected with Pseudomonas aeruginosa or pretreated with proteolytic enzymes. Infect Immun. 1986, 52, 200-204. [CrossRef]

42. Azoulay, E.; Timsit, J.F.; Tafflet, M.; de Lassence, A.; Darmon, M.; Zahar, J.R.; Adrie, C.; Garrouste-Orgeas, M.; Cohen, Y.; Mourvillier, B.; et al. Candida colonization of the respiratory tract and subsequent pseudomonas ventilator-associated pneumonia. Chest 2006, 129, 110-117. [CrossRef]

43. Diaz, P.I.; Xie, Z.; Sobue, T.; Thompson, A.; Biyikoglu, B.; Ricker, A.; Ikonomou, L.; Dongari-Bagtzoglou, A. Synergistic interaction between Candida albicans and commensal oral streptococci in a novel in vitro mucosal model. Infect Immun. 2012, 80, 620-632. [CrossRef] [PubMed]

44. Bamford, C.V.; d'Mello, A.; Nobbs, A.H.; Dutton, L.C.; Vickerman, M.M.; Jenkinson, H.F. Streptococcus gordonii modulates Candida albicans biofilm formation through intergeneric communication. Infect. Immun. 2009, 77, 3696-3704. [CrossRef] [PubMed]

45. Hoyer, L.L.; Oh, S.H.; Jones, R.; Cota, E. A proposed mechanism for the interaction between the Candida albicans Als3 adhesin and streptococcal cell wall proteins. Front. Microbiol. 2014, 5, 564. [CrossRef] [PubMed]

46. Silverman, R.J.; Nobbs, A.H.; Vickerman, M.M.; Barbour, M.E.; Jenkinson, H.F. Interaction of Candida albicans cell wall Als3 protein with Streptococcus gordonii SspB adhesin promotes development of mixed-species communities. Infect. Immun. 2010, 78, 4644-4652. [CrossRef]

47. Xu, H.; Sobue, T.; Thompson, A.; Xie, Z.; Poon, K.; Ricker, A.; Cervantes, J.; Diaz, P.I.; Dongari-Bagtzoglu, A. Streptococcal co-infection augments Candida pathogenicity by amplifying the mucosal inflammatory response. Cell. Microbiol. 2014, 16, 214-231. [CrossRef]

48. Kong, E.F.; Tsui, C.; Kucharikova, S.; Andes, D.; van Dijck, P.; Jabra-Rizk, M.A. Commensal protection of Staphylococcus aureus against antimicrobials by Candida albicans Biofilm Matrix. mBio 2016, 7, e01365-16. [CrossRef] [PubMed]

49. Adam, B.; Baillie, G.S.; Douglas, L.J. Mixed species biofilms of Candida albicans and Staphylococcus epidermidis. J. Med. Microbiol. 2002, 51, 344-349. [CrossRef]

50. Kean, R.; Rajendran, R.; Haggarty, J.; Townsend, E.M.; Short, B.; Burgess, K.E.; Lang, S.; Millington, O.; Mackay, W.G.; Williams, C.; et al. Candida albicans mycofilms support Staphylococcus aureus colonization and enhances miconazole resistance in dual-species interactions. Front. Microbiol. 2017, 8, 258. [CrossRef]

51. Pammi, M.; Liang, R.; Hicks, J.; Mistretta, T.A.; Versalovic, J. Biofilm extracellular DNA enhances mixed species biofilms of Staphylococcus epidermidis and Candida albicans. BMC Microbiol. 2013, 13, 257. [CrossRef] [PubMed]

52. Alam, F.; Catlow, D.; di Maio, A.; Blair, J.M.A.; Hall, R.A. Candida albicans enhances meropenem tolerance of Pseudomonas aeruginosa in a dual-species biofilm. J. Antimicrob. Chemother. 2020, 75, 925-935. [CrossRef]

53. Phuengmaung, P.; Somparn, P.; Panpetch, W.; Singkham-In, U.; Wannigama, D.L.; Chatsuwan, T.; Leelahavanichkul, A. Coexistence of Pseudomonas aeruginosa with Candida albicans enhances biofilm thickness through alginate-related extracellular matrix but is attenuated by N-acetyl-1-cysteine. Front. Cell Infect. Microbiol. 2020, 10, 594336. [CrossRef] [PubMed]

54. Olofsson, A.C.; Hermansson, M.; Elwing, H. N-Acetyl-l-Cysteine affects growth, extracellular polysaccharide production, and bacterial biofilm formation on solid surfaces. Appl. Environ. Microbiol. 2003, 69, 4814-4822. [CrossRef]

55. Kim, D.; Liu, Y.; Benhamou, R.I.; Sanchez, H.; Simon-Soro, A.; Li, Y.; Hwang, G.; Fridman, M.; Andes, D.R.; Koo, H. Bacterialderived exopolysaccharides enhance antifungal drug tolerance in a cross-kingdom oral biofilm. ISME J. 2018, 12, 1427-1442. [CrossRef] [PubMed]

56. Montelongo-Jauregui, D.; Saville, S.P.; Lopez-Ribot, J.L. Contributions of Candida albicans Dimorphism, Adhesive Interactions, and Extracellular Matrix to the Formation of Dual-Species Biofilms with Streptococcus gordonii. mBio 2019, 10, e01179-19. [CrossRef]

57. Orazi, G.; O'Toole, G.A. "It Takes a Village": Mechanisms Underlying antimicrobial recalcitrance of polymicrobial biofilms. J. Bacteriol. 2019, 202, e00530-19. [CrossRef]

58. Dixon, E.F.; Hall, R.A. Noisy neighbourhoods: Quorum sensing in fungal-polymicrobial infections. Cell. Microbiol. 2015, 17, 1431-1441. [CrossRef]

59. Bandara, H.; Wood, D.L.A.; Vanwonterghem, I.; Hugenholtz, P.; Cheung, B.P.K.; Samaranayake, L.P. Fluconazole resistance in Candida albicans is induced by Pseudomonas aeruginosa quorum sensing. Sci. Rep. 2020, 10, 7769. [CrossRef]

60. Hogan, D.A.; Vik, A.; Kolter, R. A Pseudomonas aeruginosa quorum-sensing molecule influences Candida albicans morphology. Mol. Microbiol. 2004, 54, 1212-1223. [CrossRef]

61. Rodrigues, C.F.; Cernakova, L. Farnesol and Tyrosol: Secondary metabolites with a crucial quorum-sensing role in Candida Biofilm Development. Genes 2020, 11, 444. [CrossRef] 
62. Kong, E.F.; Tsui, C.; Kucharikova, S.; van Dijck, P.; Jabra-Rizk, M.A. Modulation of Staphylococcus aureus response to antimicrobials by the Candida albicans quorum sensing molecule farnesol. Antimicrob. Agents Chemother. 2017, 61, e01573-17. [CrossRef]

63. Fernandes, R.A.; Monteiro, D.R.; Arias, L.S.; Fernandes, G.L.; Delbem, A.C.; Barbosa, D.B. Biofilm formation by Candida albicans and Streptococcus mutans in the presence of farnesol: A quantitative evaluation. Biofouling 2016, 32, 329-338. [CrossRef]

64. Jabra-Rizk, M.A.; Meiller, T.F.; James, C.E.; Shirtliff, M.E. Effect of farnesol on Staphylococcus aureus biofilm formation and antimicrobial susceptibility. Antimicrob. Agents Chemother. 2006, 50, 1463-1469. [CrossRef]

65. Chen, H.; Fujita, M.; Feng, Q.; Clardy, J.; Fink, G.R. Tyrosol is a quorum-sensing molecule in Candida albicans. Proc. Natl. Acad. Sci. USA 2004, 101, 5048-5052. [CrossRef]

66. Arias, L.S.; Delbem, A.C.; Fernandes, R.A.; Barbosa, D.B.; Monteiro, D.R. Activity of tyrosol against single and mixed-species oral biofilms. J. Appl. Microbiol. 2016, 120, 1240-1249. [CrossRef] [PubMed]

67. Abdel-Rhman, S.H.; El-Mahdy, A.M.; El-Mowafy, M. Effect of tyrosol and farnesol on virulence and antibiotic resistance of clinical isolates of Pseudomonas aeruginosa. Biomed. Res. Int. 2015, 2015, 456463. [PubMed]

68. Erb-Downward, J.R.; Noverr, M.C. Characterization of prostaglandin E2 production by Candida albicans. Infect. Immun. 2007, 75, 3498-3505. [CrossRef] [PubMed]

69. Krause, J.; Geginat, G.; Tammer, I. Prostaglandin E2 from Candida albicans stimulates the growth of Staphylococcus aureus in mixed biofilms. PLoS ONE 2015, 10, e0135404. [CrossRef]

70. Todd, O.A.; Fidel, P.L., Jr.; Harro, J.M.; Hilliard, J.J.; Tkaczyk, C.; Sellman, B.R.; Noverr, M.C.; Peters, B.M. Candida albicans augments Staphylococcus aureus virulence by engaging the staphylococcal agr quorum sensing system. mBio 2019, 10, e00910-19. [CrossRef]

71. Deng, L.; Zou, L.; Wu, J.; Liu, H.; Luo, T.; Zhou, X.; Li, W.; Ren, B. Voriconazole inhibits cross-kingdom interactions between Candida albicans and Actinomyces viscosus through the ergosterol pathway. Int. J. Antimicrob. Agents 2019, 53, 805-813. [CrossRef]

72. Fernandes, L.; Fortes, B.N.; Lincopan, N.; Ishida, K. Caspofungin and polymyxin B reduce the cell viability and total biomass of mixed biofilms of carbapenem-resistant Pseudomonas aeruginosa and Candida spp. Front. Microbiol. 2020, 11, 573263. [CrossRef]

73. Rogiers, O.; Holtappels, M.; Siala, W.; Lamkanfi, M.; van Bambeke, F.; Lagrou, K.; Van Dijck, P.; Kucharikova, S. Anidulafungin increases the antibacterial activity of tigecycline in polymicrobial Candida albicans/Staphylococcus aureus biofilms on intraperitoneally implanted foreign bodies. J. Antimicrob. Chemother. 2018, 73, 2806-2814. [CrossRef] [PubMed]

74. Lown, L.; Peters, B.M.; Walraven, C.J.; Noverr, M.C.; Lee, S.A. An optimized lock solution containing micafungin, ethanol and doxycycline inhibits Candida albicans and mixed, C. albicans-Staphyloccoccus aureus biofilms. PLoS ONE 2016, 11, e0159225. [CrossRef] [PubMed]

75. De Alteriis, E.; Lombardi, L.; Falanga, A.; Napolano, M.; Galdiero, S.; Siciliano, A.; Carotenuto, R.; Guida, M.; Galdiero, E. Polymicrobial antibiofilm activity of the membranotropic peptide gH625 and its analogue. Microb Pathog. 2018, 125, 189-195. [CrossRef] [PubMed]

76. Maione, A.; de Alteriis, E.; Carraturo, F.; Galdiero, S.; Falanga, A.; Guida, M.; Di Cosmo, A.; Maselli, V.; Galdiero, E. The membranotropic peptide gH625 to combat mixed Candida albicans/Klebsiella pneumoniae biofilm: Correlation between in vitro anti-biofilm activity and in vivo antimicrobial protection. J. Fungi 2021, 7, 26. [CrossRef] [PubMed]

77. Gupta, S.; Thakur, J.; Pal, S.; Gupta, R.; Mishra, D.; Kumar, S.; Yadav, K.; Saini, A.; Yavvari, P.S.; Vedantham, M.; et al. Cholic acid-peptide conjugates as potent antimicrobials against interkingdom polymicrobial biofilms. Antimicrob. Agents Chemother. 2019, 63, e00520-19. [CrossRef]

78. Qu, Y.; Locock, K.; Verma-Gaur, J.; Hay, I.D.; Meagher, L.; Traven, A. Searching for new strategies against polymicrobial biofilm infections: Guanylated polymethacrylates kill mixed fungal/bacterial biofilms. J. Antimicrob. Chemother. 2016, 71, 413-421. [CrossRef]

79. Pati, B.A.; Kurata, W.E.; Horseman, T.S.; Pierce, L.M. Antibiofilm activity of chitosan/epsilon-poly-L-lysine hydrogels in a porcine ex vivo skin wound polymicrobial biofilm model. Wound Repair Regen. 2021. [CrossRef] [PubMed]

80. Feldman, M.; Ginsburg, I.; Al-Quntar, A.; Steinberg, D. Thiazolidinedione-8 alters symbiotic relationship in C. albicans-S. mutans dual species biofilm. Front. Microbiol. 2016, 7, 140. [CrossRef]

81. Feldman, M.; Shenderovich, J.; Lavy, E.; Friedman, M.; Steinberg, D. A sustained-release membrane of thiazolidinedione-8: Effect on formation of a Candida/bacteria mixed biofilm on hydroxyapatite in a continuous flow model. Biomed. Res. Int. 2017, 2017, 3510124. [CrossRef] [PubMed]

82. Weiland-Brauer, N.; Malek, I.; Schmitz, R.A. Metagenomic quorum quenching enzymes affect biofilm formation of Candida albicans and Staphylococcus epidermidis. PLoS ONE 2019, 14, e0211366. [CrossRef]

83. Lee, J.H.; Kim, Y.G.; Khadke, S.K.; Yamano, A.; Watanabe, A.; Lee, J. Inhibition of biofilm formation by Candida albicans and polymicrobial microorganisms by nepodin via hyphal-growth suppression. ACS Infect. Dis. 2019, 5, 1177-1187. [CrossRef]

84. Gao, S.; Liu, G.; Li, J.; Chen, J.; Li, L.; Li, Z.; Zhang, X.; Zhang, S.; Thorne, R.F.; Zhang, S. Antimicrobial activity of lemongrass essential oil (Cymbopogon flexuosus) and its active component citral against dual-species biofilms of Staphylococcus aureus and Candida species. Front. Cell Infect. Microbiol. 2020, 10, 603858. [CrossRef]

85. Pekmezovic, M.; Aleksic, I.; Barac, A.; Arsic-Arsenijevic, V.; Vasiljevic, B.; Nikodinovic-Runic, J.; Senerovic, L. Prevention of polymicrobial biofilms composed of Pseudomonas aeruginosa and pathogenic fungi by essential oils from selected Citrus species. Pathog Dis. 2016, 74, ftw102. [CrossRef] [PubMed] 
86. Jafri, H.; Khan, M.S.A.; Ahmad, I. In vitro efficacy of eugenol in inhibiting single and mixed-biofilms of drug-resistant strains of Candida albicans and Streptococcus mutans. Phytomedicine 2019, 54, 206-213. [CrossRef] [PubMed]

87. Tan, Y.; Leonhard, M.; Moser, D.; Ma, S.; Schneider-Stickler, B. Antibiofilm efficacy of curcumin in combination with 2aminobenzimidazole against single- and mixed-species biofilms of Candida albicans and Staphylococcus aureus. Colloids Surf. B Biointerfaces 2019, 174, 28-34. [CrossRef] [PubMed]

88. Raorane, C.J.; Lee, J.H.; Kim, Y.G.; Rajasekharan, S.K.; Garcia-Contreras, R.; Lee, J. Antibiofilm and antivirulence efficacies of flavonoids and curcumin against Acinetobacter baumannii. Front. Microbiol. 2019, 10, 990. [CrossRef] [PubMed]

89. Scaffaro, R.; Lopresti, F.; D'Arrigo, M.; Marino, A.; Nostro, A. Efficacy of poly(lactic acid)/carvacrol electrospun membranes against Staphylococcus aureus and Candida albicans in single and mixed cultures. Appl. Microbiol. Biotechnol. 2018, 102, $4171-4181$. [CrossRef]

90. Campbell, M.; Fathi, R.; Cheng, S.Y.; Ho, A.; Gilbert, E.S. Rhamnus prinoides (gesho) stem extract prevents co-culture biofilm formation by Streptococcus mutans and Candida albicans. Lett. Appl. Microbiol. 2020, 71, 294-302. [CrossRef]

91. Palma, A.; Paula-Ramos, L.; Domingues, N.; Back-Brito, G.N.; de Oliveira, L.D.; Pereira, C.A.; Jorge, A.O.C. Biofilms of Candida albicans and Streptococcus sanguinis and their susceptibility to antimicrobial effects of photodynamic inactivation. Photodiagnosis Photodyn. Ther. 2018, 24, 95-101. [CrossRef]

92. Pourhajibagher, M.; Ghorbanzadeh, R.; Bahador, A. Antimicrobial properties of acrylic resins doped with Undaria pinnatifida exposed to light-emitting diode: In silico and in vitro assessments on multispecies biofilm-producing microbiota. Photodiagnosis Photodyn. Ther. 2019, 27, 210-215. [CrossRef] [PubMed]

93. Diogo, P.; Fernandes, C.; Caramelo, F.; Mota, M.; Miranda, I.M.; Faustino, M.A.F.; Neves, M.G.P.M.S.; Uliana, M.P.; de Oliveira, K.T.; Santos, J.M. Antimicrobial photodynamic therapy against endodontic Enterococcus faecalis and Candida albicans mono and mixed biofilms in the presence of photosensitizers: A comparative study with classical endodontic irrigants. Front Microbiol. 2017, 8, 498. [CrossRef]

94. Tan, Y.; Leonhard, M.; Moser, D.; Ma, S.; Schneider-Stickler, B. Long-term antibiofilm activity of carboxymethyl chitosan on mixed biofilm on silicone. Laryngoscope 2016, 126, E404-E408. [CrossRef]

95. Tan, Y.; Leonhard, M.; Moser, D.; Ma, S.; Schneider-Stickler, B. Inhibition of mixed fungal and bacterial biofilms on silicone by carboxymethyl chitosan. Colloids Surf. B Biointerfaces 2016, 148, 193-199. [CrossRef]

96. Tan, Y.; Leonhard, M.; Ma, S.; Moser, D.; Schneider-Stickler, B. Efficacy of carboxymethyl chitosan against Candida tropicalis and Staphylococcus epidermidis monomicrobial and polymicrobial biofilms. Int. J. Biol. Macromol. 2018, 110, 150-156. [CrossRef] [PubMed]

97. Ramasamy, M.; Lee, J. Recent nanotechnology approaches for prevention and treatment of biofilm-associated infections on medical devices. BioMed Res. Int. 2016, 2016, 1851242. [CrossRef] [PubMed]

98. Yetisgin, A.A.; Cetinel, S.; Zuvin, M.; Kosar, A.; Kutlu, O. Therapeutic nanoparticles and their targeted delivery applications. Molecules 2020, 25, 2193. [CrossRef] [PubMed]

99. Hager, C.L.; Isham, N.; Schrom, K.P.; Chandra, J.; McCormick, T.; Miyagi, M.; Ghannoum, M.A. Effects of a novel probiotic combination on pathogenic bacterial-fungal polymicrobial biofilms. mBio 2019, 10, e00338-19. [CrossRef]

100. Tan, Y.; Leonhard, M.; Moser, D.; Schneider-Stickler, B. Inhibition activity of Lactobacilli supernatant against fungal-bacterial multispecies biofilms on silicone. Microb. Pathog. 2017, 113, 197-201. [CrossRef]

101. Krzysciak, W.; Koscielniak, D.; Papiez, M.; Vyhouskaya, P.; Zagorska-Swiezy, K.; Kolodziej, I.; Bystrowska, B.; Jurczak, A. Effect of a Lactobacillus salivarius probiotic on a double-species Streptococcus mutans and Candida albicans caries biofilm. Nutrients 2017, 9, 1242. [CrossRef]

102. Mahlapuu, M.; Hakansson, J.; Ringstad, L.; Bjorn, C. Antimicrobial peptides: An emerging category of therapeutic agents. Front. Cell. Infect. Microbiol. 2016, 6, 194. [CrossRef] [PubMed]

103. Buda De Cesare, G.; Cristy, S.A.; Garsin, D.A.; Lorenz, M.C. Antimicrobial peptides: A new frontier in antifungal therapy. $m$ Bio 2020, 11, e02123-20. [CrossRef] [PubMed]

104. Marr, A.K.; Gooderham, W.J.; Hancock, R.E. Antibacterial peptides for therapeutic use: Obstacles and realistic outlook. Curr. Opin. Pharmacol. 2006, 6, 468-472. [CrossRef] [PubMed]

105. Galdiero, S.; Falanga, A.; Morelli, G.; Galdiero, M. gH625: A milestone in understanding the many roles of membranotropic peptides. Biochim. Biophys. Acta 2015, 184, 16-25. [CrossRef]

106. Falanga, A.; Valiante, S.; Galdiero, E.; Franci, G.; Scudiero, O.; Morelli, G.; Galdiero, S. Dimerization in tailoring uptake efficacy of the HSV-1 derived membranotropic peptide gH625. Sci. Rep. 2017, 7, 9434. [CrossRef]

107. Lai, X.Z.; Feng, Y.; Pollard, J.; Chin, J.N.; Rybak, M.J.; Bucki, R.; Epand, R.F.; Epand, R.M.; Savage, P.B. Ceragenins: Cholic acid-based mimics of antimicrobial peptides. Acc. Chem. Res. 2008, 41, 1233-1340. [CrossRef] [PubMed]

108. Yadav, K.; Kumar, S.; Mishra, D.; Asad, M.; Mitra, M.; Yavvari, P.S.; Gupta, S.; Vendantham, M.; Ranga, P.; Komalla, V.; et al. Deciphering the role of intramolecular networking in cholic acid-peptide conjugates on the lipopolysaccharide surface in combating gram-negative bacterial infections. J. Med. Chem. 2019, 62, 1875-1886. [CrossRef]

109. Locock, K.E.; Michl, T.D.; Valentin, J.D.; Vasilev, K.; Hayball, J.D.; Qu, Y.; Traven, A.; Griesser, H.J.; Meagher, L.; Haeussler, M. Guanylated polymethacrylates: A class of potent antimicrobial polymers with low hemolytic activity. Biomacromolecules 2013, 14, 4021-4031. [CrossRef] [PubMed] 
110. Brackman, G.; Al Quntar, A.A.; Enk, C.D.; Karalic, I.; Nelis, H.J.; van Calenbergh, S.; Srebnik, M.; Coenye, T. Synthesis and evaluation of thiazolidinedione and dioxazaborocane analogues as inhibitors of AI-2 quorum sensing in Vibrio harveyi. Bioorg. Med. Chem. 2013, 21, 660-667. [CrossRef]

111. Kagan, S.; Jabbour, A.; Sionov, E.; Alquntar, A.A.; Steinberg, D.; Srebnik, M.; Nir-Paz, R.; Weiss, A.; Polacheck, I. Anti-Candida albicans biofilm effect of novel heterocyclic compounds. J. Antimicrob. Chemother. 2014, 69, 416-427. [CrossRef] [PubMed]

112. Feldman, M.; Al-Quntar, A.; Polacheck, I.; Friedman, M.; Steinberg, D. Therapeutic potential of thiazolidinedione-8 as an antibiofilm agent against Candida albicans. PLoS ONE 2014, 9, e93225. [CrossRef] [PubMed]

113. Feldman, M.; Shenderovich, J.; Al-Quntar, A.A.; Friedman, M.; Steinberg, D. Sustained release of a novel anti-quorum-sensing agent against oral fungal biofilms. Antimicrob. Agents Chemother. 2015, 59, 2265-2272. [CrossRef]

114. Gajdacs, M.; Spengler, G. The role of drug repurposing in the development of novel antimicrobial drugs: Non-antibiotic pharmacological agents as quorum sensing-inhibitors. Antibiotics 2019, 8, 270. [CrossRef]

115. Horvath, G.; Acs, K. Essential oils in the treatment of respiratory tract diseases highlighting their role in bacterial infections and their anti-inflammatory action: A review. Flavour. Fragr. J. 2015, 30, 331-341. [CrossRef] [PubMed]

116. Feyaerts, A.F.; Mathe, L.; Luyten, W.; de Graeve, S.; van Dyck, K.; Broekx, L.; Van Dijck, P. Essential oils and their components are a class of antifungals with potent vapour-phase-mediated anti-Candida activity. Sci. Rep. 2018, 8, 3958. [CrossRef]

117. Trifan, A.; Luca, S.V.; Greige-Gerges, H.; Miron, A.; Gille, E.; Aprotosoaie, A.C. Recent advances in tackling microbial multidrug resistance with essential oils: Combinatorial and nano-based strategies. Crit. Rev. Microbiol. 2020, 46, 338-357. [CrossRef]

118. D'Agostino, M.; Tesse, N.; Frippiat, J.P.; Machouart, M.; Debourgogne, A. Essential oils and their natural active compounds presenting antifungal properties. Molecules 2019, 24, 3713. [CrossRef]

119. Zouhir, A.; Jridi, T.; Nefzi, A.; Ben Hamida, J.; Sebei, K. Inhibition of methicillin-resistant Staphylococcus aureus (MRSA) by antimicrobial peptides (AMPs) and plant essential oils. Pharm. Biol. 2016, 54, 3136-3150. [CrossRef]

120. de Silva, C.B.; Guterres, S.S.; Weisheimer, V.; Schapoval, E.E. Antifungal activity of the lemongrass oil and citral against Candida spp. Braz. J. Infect. Dis. 2008, 12, 63-66. [CrossRef]

121. Valliammai, A.; Sethupathy, S.; Ananthi, S.; Priya, A.; Selvaraj, A.; Nivetha, V.; Aravindraja, C.; Mahalingam, S.; Pandian, S.K. Proteomic profiling unveils citral modulating expression of IsaA, CodY and SaeS to inhibit biofilm and virulence in methicillinresistant Staphylococcus aureus. Int. J. Biol. Macromol. 2020, 20, 33095-33096. [CrossRef]

122. Budzynska, A.; Rozalska, S.; Sadowska, B.; Rozalska, B. Candida albicans/Staphylococcus aureus dual-species biofilm as a target for the combination of essential oils and fluconazole or mupirocin. Mycopathologia 2017, 182, 989-995. [CrossRef]

123. Chattopadhyay, I.; Biswas, K.; Bandyopadhyay, U.; Banerjee, R.K. Turmeric and curcumin: Biological actions and medicinal applications. Curr. Sci. 2004, 87, 44-53.

124. Ma, S.; Moser, D.; Han, F.; Leonhard, M.; Schneider-Stickler, B.; Tan, Y. Preparation and antibiofilm studies of curcumin loaded chitosan nanoparticles against polymicrobial biofilms of Candida albicans and Staphylococcus aureus. Carbohydr. Polym. 2020, 241, 116254. [CrossRef] [PubMed]

125. Chami, F.; Chami, N.; Bennis, S.; Trouillas, J.; Remmal, A. Evaluation of carvacrol and eugenol as prophylaxis and treatment of vaginal candidiasis in an immunosuppressed rat model. J. Antimicrob. Chemother. 2004, 54, 909-914. [CrossRef] [PubMed]

126. Chami, N.; Chami, F.; Bennis, S.; Trouillas, J.; Remmal, A. Antifungal treatment with carvacrol and eugenol of oral candidiasis in immunosuppressed rats. Braz. J. Infect. Dis. 2004, 8, 217-226. [CrossRef] [PubMed]

127. Huang, L.; Dai, T.; Hamblin, M.R. Antimicrobial photodynamic inactivation and photodynamic therapy for infections. Methods Mol. Biol. 2010, 635, 155-173.

128. Stajer, A.; Kajari, S.; Gajdacs, M.; Musah-Eroje, A.; Barath, Z. Utility of photodynamic therapy in dentistry: Current concepts. Dent. J. 2020, 8, 43. [CrossRef]

129. Pereira, C.A.; Romeiro, R.L.; Costa, A.C.; Machado, A.K.; Junqueira, J.C.; Jorge, A.O. Susceptibility of Candida albicans, Staphylococcus aureus, and Streptococcus mutans biofilms to photodynamic inactivation: An in vitro study. Lasers Med. Sci. 2011, 26, 341-348. [CrossRef]

130. Tome, F.M.; Paula Ramos, L.; Freire, F.; Pereira, C.A.; de Oliveira, I.C.B.; Junqueira, J.C.; Jorge, A.O.C.; Oliveira, L.D. Influence of sucrose on growth and sensitivity of Candida albicans alone and in combination with Enterococcus faecalis and Streptococcus mutans to photodynamic therapy. Lasers Med. Sci. 2017, 32, 1237-1243. [CrossRef]

131. Shariatinia, Z. Carboxymethyl chitosan: Properties and biomedical applications. Int. J. Biol. Macromol. 2018, 120, 1406-1419. [CrossRef]

132. Hajipour, M.J.; Fromm, K.M.; Ashkarran, A.A.; Jimenez de Aberasturi, D.; de Larramendi, I.R.; Rojo, T.; Serpooshan, V.; Parak, W.J.; Mahmoudi, M. Antibacterial properties of nanoparticles. Trends Biotechnol. 2012, 30, 499-511. [CrossRef] [PubMed]

133. Hoseinzadeh, E.; Makhdoumi, P.; Taha, P.; Hossini, H.; Stelling, J.; Kamal, M.A.; Ashraf, G.M. A review on nano-antimicrobials: Metal nanoparticles, methods and mechanisms. Curr. Drug. Metab. 2017, 18, 120-128. [CrossRef]

134. Lopes, D.; Nunes, C.; Martins, M.C.; Sarmento, B.; Reis, S. Eradication of Helicobacter pylori: Past, present and future. J. Control. Release 2014, 189, 169-186. [CrossRef]

135. Masurkar, S.A.; Chaudhari, P.R.; Shidore, V.B.; Kamble, S.P. Effect of biologically synthesised silver nanoparticles on Staphylococcus aureus biofilm quenching and prevention of biofilm formation. IET Nanobiotechnol. 2012, 6, 110-114. [CrossRef] [PubMed] 
136. Trigo Gutierrez, J.K.; Zanatta, G.C.; Ortega, A.L.M.; Balastegui, M.I.C.; Sanitá, P.V.; Pavarina, A.C.; Barbugli, P.A.; Mima, E.G.O. Encapsulation of curcumin in polymeric nanoparticles for antimicrobial ohotodynamic therapy. PLoS ONE 2017, 12, e0187418. [CrossRef]

137. Tan, Y.; Ma, S.; Leonhard, M.; Moser, D.; Ludwig, R.; Schneider-Stickler, B. Co-immobilization of cellobiose dehydrogenase and deoxyribonuclease I on chitosan nanoparticles against fungal/bacterial polymicrobial biofilms targeting both biofilm matrix and microorganisms. Mat. Sci. Eng. C Mater. Biol. Appl. 2020, 108, 110499. [CrossRef] [PubMed]

138. Elshinawy, M.I.; Al-Madboly, L.A.; Ghoneim, W.M.; El-Deeb, N.M. Synergistic effect of newly introduced root canal medicaments; ozonated olive oil and chitosan nanoparticles, against persistent endodontic pathogens. Front. Microbiol. 2018, 9, 1371. [CrossRef]

139. Ikono, R.; Vibriani, A.; Wibowo, I.; Saputro, K.E.; Muliawan, W.; Bachtiar, B.M.; Mardliyati, E.; Bachtiar, E.W.; Rochman, N.; Kagami, H.; et al. Nanochitosan antimicrobial activity against Streptococcus mutans and Candida albicans dual-species biofilms. BMC Res. Notes 2019, 12, 383. [CrossRef]

140. Lemoine, V.; Bernard, C.; Leman-Loubiere, C.; Clement-Larosiere, B.; Girardot, M.; Boudesocque-Delaye, L.; Munnier, E.; Imbert, C. Nanovectorized microalgal extracts to fight Candida albicans and Cutibacterium acnes biofilms: Impact of dual-species conditions. Antibiotics 2020, 9, 279. [CrossRef]

141. Tokajuk, G.; Niemirowicz, K.; Deptuła, P.; Piktel, E.; Cieśluk, M.; Wilczewska, A.Z.; Dabrowski, J.R.; Bucki, R. Use of magnetic nanoparticles as a drug delivery system to improve chlorhexidine antimicrobial activity. Int. J. Nanomed. 2017, 12, 7833-7846. [CrossRef]

142. Vieira, A.P.M.; Arias, L.S.; de Souza Neto, F.N.; Kubo, A.M.; Lima, B.H.R.; de Camargo, E.R.; Pessan, J.P.; Delbem, A.C.B.; Monteiro, D.R. Antibiofilm effect of chlorhexidine-carrier nanosystem based on iron oxide magnetic nanoparticles and chitosan. Coll. Surfaces B Biointerfaces 2019, 174, 224-231. [CrossRef]

143. Arias, L.S.; Brown, J.L.; Butcher, M.C.; Delaney, C.; Monteiro, D.R.; Ramage, G. A nanocarrier system that potentiates the effect of miconazole within different interkingdom biofilms. J. Oral Microbiol. 2020, 12, 1771071. [CrossRef]

144. Arias, L.S.; Pessan, J.P.; de Souza Neto, F.N.; Lima, B.H.R.; de Camargo, E.R.; Ramage, G.; Delbem, A.C.B.; Monteiro, D.R. Novel nanocarrier of miconazole based on chitosan-coated iron oxide nanoparticles as a nanotherapy to fight Candida biofilms. Coll. Surf. B Biointerfaces 2020, 192, 111080. [CrossRef] [PubMed]

145. Kanugala, S.; Jinka, S.; Puvvada, N.; Banerjee, R.; Kumar, C.G. Phenazine-1-carboxamide functionalized mesoporous silica nanoparticles as antimicrobial coatings on silicone urethral catheters. Sci. Rep. 2019, 9, 6198. [CrossRef] [PubMed]

146. Romero-Urbina, D.G.; Lara, H.H.; Velázquez-Salazar, J.J.; Arellano-Jiménez, M.J.; Larios, E.; Srinivasan, A.; Lopez-Ribot, J.L.; Yacaman, M.J. Ultrastructural changes in methicillin-resistant Staphylococcus aureus induced by positively charged silver nanoparticles. Beilstein. J. Nanotechnol. 2015, 6, 2396-2405. [CrossRef] [PubMed]

147. Lara, H.H.; Lopez-Ribot, J.L. Inhibition of mixed biofilms of Candida albicans and methicillin-resistant Staphylococcus aureus by positively charged silver nanoparticles and functionalized silicone elastomers. Pathogens 2020, 9, 784. [CrossRef] [PubMed]

148. Hůlková, M.; Soukupová, J.; Carlson, R.P.; Maršálek, B. Interspecies interactions can enhance Pseudomonas aeruginosa tolerance to surfaces functionalized with silver nanoparticles. Coll. Surf B Biointerfaces 2020, 192, 111027. [CrossRef]

149. Lethongkam, S.; Daengngam, C.; Tansakul, C.; Siri, R.; Chumpraman, A.; Phengmak, M.; Voravuthikunchai, S.P. Prolonged inhibitory effects against planktonic growth, adherence, and biofilm formation of pathogens causing ventilator-associated pneumonia using a novel polyamide/silver nanoparticle composite-coated endotracheal tube. Biofouling 2020, 36, 292-307. [CrossRef] [PubMed]

150. Dovigo, L.N.; Pavarina, A.C.; Ribeiro, A.P.; Brunetti, I.L.; Costa, C.A.; Jacomassi, D.P.; Bagnato, V.S.; Kurachi, C. Investigation of the photodynamic effects of curcumin against Candida albicans. Photochem. Photobiol. 2011, 87, 895-903. [CrossRef]

151. Hamblin, M.R. Antimicrobial photodynamic inactivation: A bright new technique to kill resistant microbes. Curr. Opin. Microbiol. 2016, 33, 67-73. [CrossRef] [PubMed]

152. Salton, M.R. The adsorption of cetyltrimethylammonium bromide by bacteria, its action in releasing cellular constituents and its bactericidal effects. J. Gen. Microbiol. 1951, 5, 391-404. [CrossRef] [PubMed]

153. Pinto, R.M.; Soares, F.A.; Reis, S.; Nunes, C.; Van Dijck, P. Innovative strategies toward the disassembly of the EPS matrix in bacterial biofilms. Front. Microbiol. 2020, 11, 952. [CrossRef]

154. Ma, S.; Preims, M.; Piumi, F.; Kappel, L.; Seiboth, B.; Record, E.; Kracher, D.; Ludwig, R. Molecular and catalytic properties of fungal extracellular cellobiose dehydrogenase produced in prokaryotic and eukaryotic expression systems. Microb. Cell Factories 2017, 16, 37. [CrossRef] [PubMed]

155. Linley, E.; Denyer, S.P.; McDonnell, G.; Simons, C.; Maillard, J.Y. Use of hydrogen peroxide as a biocide: New consideration of its mechanisms of biocidal action. J. Antimicrobial Chemother. 2012, 67, 1589-1596. [CrossRef]

156. Tetz, G.V.; Artemenko, N.K.; Tetz, V.V. Effect of DNase and antibiotics on biofilm characteristics. Antimicrob. Agents Chemother. 2009, 53, 1204-1209. [CrossRef]

157. Rodrigues, G.R.; López-Abarrategui, C.; de la Serna Gómez, I.; Dias, S.C.; Otero-González, A.J.; Franco, O.L. Antimicrobial magnetic nanoparticles based-therapies for controlling infectious diseases. Int. J. Pharm. 2019, 555, 356-367. [CrossRef]

158. Nenoff, P.; Koch, D.; Krüger, C.; Drechsel, C.; Mayser, P. New insights on the antibacterial efficacy of miconazole in vitro. Mycoses 2017, 60, 552-557. [CrossRef] 
159. Hoarau, G.; Mukherjee, P.K.; Gower-Rousseau, C.; Hager, C.; Chandra, J.; Retuerto, M.A.; Neut, C.; Vermeire, S.; Clemente, J.; Colombel, J.F.; et al. Bacteriome and mycobiome interactions underscore microbial dysbiosis in familial Crohn's disease. $m$ Bio 2016, 7, e01250-16. [CrossRef]

160. Hager, C.L.; Ghannoum, M.A. The mycobiome: Role in health and disease, and as a potential probiotic target in gastrointestinal disease. Dig. Liver. Dis. 2017, 49, 1171-1176. [CrossRef]

161. Steenackers, H.P.; Ermolat'ev, D.S.; Savaliya, B.; De Weerdt, A.; De Coster, D.; Shah, A.; Van der Eycken, E.V.; De Vos, D.E.; Vanderleyden, J.; De Keersmaecker, S.C.J. Structure-activity relationship of 4(5)-aryl-2-amino-1H-imidazoles, N1-substituted 2-aminoimidazoles and imidazo[1,2-a]pyrimidinium salts as inhibitors of biofilm formation by Salmonella typhimurium and Pseudomonas aeruginosa. J. Med. Chem. 2011, 54, 472-484. [CrossRef] [PubMed]

162. Peeters, E.; Hooyberghs, G.; Robijns, S.; Waldrant, K.; De Weerdt, A.; Delattin, N.; Liebens, V.; Kucharikova, S.; Tournu, H.; Verstraeten, N.; et al. Modulation of the substitution pattern of 5-aryl-2-aminoimidazoles allows fine-tuning of their antibiofilm activity spectrum and toxicity. Antimicrob. Agents Chemother. 2016, 60, 6483-6497. [CrossRef] [PubMed]

163. Yassin, S.A.; German, M.J.; Rolland, S.L.; Rickard, A.H.; Jakubovics, N.S. Inhibition of multispecies biofilms by a fluoride-releasing dental prosthesis copolymer. J. Dent. 2016, 48, 62-70. [CrossRef]

164. Pires, D.P.; Melo, L.; Vilas Boas, D.; Sillankorva, S.; Azeredo, J. Phage therapy as an alternative or complementary strategy to prevent and control biofilm-related infections. Curr. Opin. Microbiol. 2017, 39, 48-56. [CrossRef]

165. Tkhilaishvili, T.; Wang, L.; Perka, C.; Trampuz, A.; Gonzalez Moreno, M. Using bacteriophages as a trojan horse to the killing of dual-species biofilm formed by Pseudomonas aeruginosa and methicillin resistant Staphylococcus aureus. Front. Microbiol. 2020, 11, 695. [CrossRef] [PubMed]

166. Akturk, E.; Oliveira, H.; Santos, S.B.; Costa, S.; Kuyumcu, S.; Melo, L.D.R.; Azeredo, J. Synergistic Action of Phage and Antibiotics: Parameters to Enhance the Killing Efficacy Against Mono and Dual-Species Biofilms. Antibiotics 2019, 8, 103. [CrossRef] [PubMed]

167. Gorski, A.; Bollyky, P.L.; Przybylski, M.; Borysowski, J.; Miedzybrodzki, R.; Jonczyk-Matysiak, E.; Weber-Dabrowska, B. Perspectives of Phage Therapy in Non-bacterial Infections. Front. Microbiol. 2018, 9, 3306. [CrossRef]

168. Penner, J.C.; Ferreira, J.A.G.; Secor, P.R.; Sweere, J.M.; Birukova, M.K.; Joubert, L.M.; Haagensen, J.A.J.; Garcia, O.; Malkovskiy, A.V.; Kaber, G.; et al. Pf4 bacteriophage produced by Pseudomonas aeruginosa inhibits Aspergillus fumigatus metabolism via iron sequestration. Microbiology 2016, 162, 1583-1594. [CrossRef] [PubMed]

169. Nazik, H.; Joubert, L.M.; Secor, P.R.; Sweere, J.M.; Bollyky, P.L.; Sass, G.; Cegelski, L.; Stevens, D.A. Pseudomonas phage inhibition of Candida albicans. Microbiology 2017, 163, 1568-1577. [CrossRef]

170. Gajdacs, M. The Concept of an Ideal Antibiotic: Implications for Drug Design. Molecules 2019, 24, 892. [CrossRef] 